\title{
SOME PROBLEMS OF EXEMPTION UNDER THE SECURITIES ACT OF 1933
}

\author{
Allen E. Throop* and Chester T. Lane†
}

The writers have sought in this article to review briefly the history and scope of those provisions of the Securities Act of 1933 , as amended, which exempt specified securities or transactions from the registration and prospectus requirements of the Act, and to discuss. in some detail certain problems which have arisen in the application of these provisions. In their discussion of these problems, the writers have, with the consent of the Securities and Exchange Commission, made generous use of the body of interpretative material evolved in the course of consideration of questions presented by lawyers and laymen for advisory opinions of the General Counsel. However, although in many instances the situations discussed will have had some counterpart in matters which have thus been brought to the attention of the General Counsel, any opinions advanced herein are, unless the contrary is specifically indicated, to be regarded merely as the writers' personal views, and not as necessarily reflecting the previous expression of corresponding advisory opinions.

Any consideration of specific problems arising under the exemptive provisions of the Securities Act of 1933 , as amended, ${ }^{1}$ requires an initial survey of the general character of securities and transactions exempted and of the effect of the exemption thus afforded. Broadly speaking, the Act, by Section 5 thereof, prohibits the use of the mails or any means or instruments of transportation or communication in interstate commerce to offer, sell or deliver after sale any security except in accordance with specified registration and prospectus requirements. In addition, Section 17 makes unlawful the use of any such means for the sale of securities by fraudulent or mis-

- A.B., r921, Hamilton College; A.M., I922, Harvard; LL.B., 1925, S.J.D., 1926, Harvard Law School. Member of New York Bar. General Counsel, Securities and Exchange Commission, since January 15, 1937; Assistant General Counsel from September 1934. Associated with Cotton, Franklin, Wright and Gordon, New York, I926 to I934, except during period of appointment for several months in I932 as Counsel for Reconstruction Finance Corporation. Secrctary of Foreign Bondholders Protective Council, Inc., New York, March 1934 to September 1934.

† A.B., 1926, LL.B., 1930, Harvard. Member of New York Bar. Assistant General Ccunsel, Securities and Exchange Commission, since January 15, 1937; on staff of General Counsel from October, I935. Associated with Milbank, Tweed, Hope \& Webb, New York, 1930-1935.

The writers wish to acknowledge the valuable assistance rendered them by Mr. M. Quinn Shaughnessy, a member of the legal staff of the Securities and Exchange Commission.

${ }^{1}$ Public Law No. 22 of the 73rd Congress, approved May 27, 1933, consists of two titles, the first of which is designated therein as the "Securities Act of 1933," and the second of which is designated therein 25 the "Corporation of Foreign Bondholders Act, 1933." 48 STAT. 74, 15 U. S. C., \$772. Title I, the Securities Act of 1933, has been amended by Title II of the Securities Exchange Act of 1934, 48 STAT. 881, and also, in one relatively unimportant respect, by the Motor Carrier Act of 1935, 49 Srar. 543, 49 U. S. C. \$\$30r-327. 
leading methods. In aid of the express prohibitions of Sections 5 and 17 , Section 12 vests in the purchaser of any security sold in contravention of such prohibitions a right to rescind his purchase, or to recover damages if he no longer owns the security. In terms, the prohibitions of the Act apply to all transactions involving sales of securities through the mails or instrumentalities of interstate commerce, regardless of the nature of the securities so sold, or the character of the persons by whom such sales are effected.

Except as regards fraud or negligent misrepresentation on the part of the seller, however, the administrative provisions of the Act are primarily directed to the problem of distribution, as distinguished from that of trading. Furthermore, in the drafting of the Act it was evidently appreciated that there existed numerous types of securities and of distributions to which a system of centralized supervision by the federal government would be either unnecessary or inappropriate. In recognition of these limitations, specific classes of securities and of transactions are expressly exempted from the general prohibitions established by Section 5 of the Act. This article is primarily concerned with certain problems of interpretation created by the sections of the Act providing for such exemptions.

The exemptive provisions are contained in Sections 3 and 4 of the Act, ${ }^{2}$ and in Sections $77(f)$ and $77 \mathrm{~B}(\mathrm{~h})$ of the Bankruptcy Act. Except as to transactions in the securities of banking institutions and of federal and state governments and their instrumentalities, ${ }^{3}$ the exemption afforded does not in effect extend beyond the exemption of specified securities and specified transactions from compliance with the registration and prospectus requirements of the Act. ${ }^{4}$ It follows that in all trans-

'Section $5(c)$, as originally adopted, was in effect also an exemptive provision. However, by amendment of the Act in 1934, this section was deleted and a somewhat similar provision substituted as $S_{3}(\mathrm{a})(\mathrm{Ir})$.

s $\$_{3}(a)(2)$. For a more complete enumeration of such securitics, see p. 92, infra.

"Section "3, entitled "Exempted Securities", provides: "Except as hereinafter expressly provided, the provisions of this title shall not apply to any of the following classes of securities: . . " Section 12, which in clause (2) thereof imposes civil liabilities for misrepresentation in the sale of securities, provides that it is applicable to the sale of a security "whether or not exempted by the provisions of section 3 , other than paragraph (2) of subsection (a) thereof"; and 517 , prohibiting fraudulent security transactions involving the use of the mails or interstate commerce and the fraudulent "puffing" of securities by such means, provides: "The exemptions provided in section 3 shall not apply to the provisions of this section." Section 4, entitled "Exempted Transactions," provides: "The provisions of section 5 shall not apply to any of the following transactions: ..."

The limited scope of the exemption afforded by $\$ 77 \mathrm{~B}(\mathrm{~h})$ of the Bankruptcy Act is relatively clear. The securities specified therein are stated to be exempt "from all the provisions of the Securities Act of 1933, approved May 27, 1933, except the provisions of subdivision (2) of section 12, and section 17 thereof, and except the provisions of section 24 thereof as applied to any willful violation of said section I7." 48 STAT. 9I I (1934), II U. S. C. $\$ 207(\mathrm{~h})$. Section $77(\mathrm{f})$ of the Bankruptcy Act, with less clarity, provides in part: "The provisions of title $I$ and of section 5 of the Securities Act of 1933, as amended, shall not apply to the issuance, sale, or exchange of any of the following securities, which securities and transactions therein shall, for the purposes of said Securities Act, be treated as if they were specifically mentioned in sections 3 and 4 of the said Securities Act, respectively: . . ." (Italics supplied.) 49 STAт. 9 II (I935), II U. S. C. A. 3205 (f). The text of this provision is obviously self-contradictory, in that the mention of a security in 53 or a transaction in 54 does not, under the provisions of those sections, exempt the security or transaction from all the provisions of Title I of the Act. Yet the clause quoted above provides that "the provisions of title I . . . shall not apply". It is submitted that the more specific 
actions in which securities, other than those specified above, are sold by the use of any means or instruments of transportation or communication in interstate commerce or of the mails, by means of a prospectus or oral communication, the seller may be required to respond to the purchaser in damages if such prospectus or communication is misleading by reason of the seller's fraud or negligence, regardless of the exempt status of the securities. Furthermore, the prohibitions of the Act against fraudulent transactions, and the remedial and penal provisions supporting such prohibitions, apply to transactions in all securities regardless of their "exempt" status. ${ }^{5}$

The exemptive provisions of the Act may be classified as:

First: Provisions exempting securities by reason of the character of the issuer.

Second: Provisions exempting securities by reason of the character of the security or the issue of which the security is a part, regardless of the character of the issuer.

Third: Provisions exempting securities by reason of the manner of their distribution, regardless of the character of the issuer, the security, or the issue of which it is a part.

Fourth: Provisions exempting particular classes of transactions, regardless of the character of the issuer, the security, the issue of which the security is a part, or the manner in which the security was originally distributed.

In an article of the present compass it is hardly feasible to attempt an exhaustive analysis of the problems presented in respect of each type of security or transaction comprehended within the general classifications outlined above. It is therefore proposed to summarize briefly the nature of the exemptive provisions which rest upon the character of the issuer or the character of the security or issue of which it is a part, and then to discuss in some detail certain questions arising out of the exemptive provisions comprehended within the third and fourth classifications referred to above. ${ }^{6}$

\footnotetext{
language in the provision would govern the more general, and that, in the absence of judicial decision to the contrary, it may be assumed that $\$ \$ 12(2), 17$ and 24 are applicable to the securitics and tic:asdctions specified in $\$ 77(f)$ of the Bankruptcy Act.

${ }^{B}$ This statement is subject to possible qualification with respect to the application of injunctive remedies under $\$ 20$ to securities exempted by $\$ \$ 77(f)$ and $77 \mathrm{~B}(h)$ of the Bankruptcy Act, supre note 4 .

- Essential to an appreciation of the problems of exemption under the Securities Act is an understanding of the fact that the exemptive provisions are self-executing. Exemption depends not upon any finding or approval by the Commission, but upon factual compliance with the-conditions of the particular provision under which exemption is sought: and even in cascs where these conditions include the filing of papers with the Commission, as in the case of certain of the exempting regulations adopted by the Commission under $\S_{3}(b)$ of the Act, there is no provision for the taking of any action by the Commission to establish the exemption. Since the amendment of $\$ 19$ of the Act in 1934 , the Commission has, it is true, the power by rule or regulation to define technical as well as accounting and trade terms; and, in addition, 519 as amended contains the following provision: "No provision of this title imposing any liability shall apply to any act done or omitted in good faith in conformity with any rule or regulation of the Commission, notwithstanding that such rule or regulation may, after such act or omission, be amended or rescinded or be determined by judicial or other authority to be invalid for any reason."

The wisdom of this latter provision is obvious and its soundness both as a matter of legislative policy and on constitutional grounds has received full discussion (See Cook, Certainty in the Construction of the Law, 21 A. B. A. J. 19 to 21 ). However, the Commission has not regarded this provision as an authorization to it to proceed freely in the promulgation of rcgulations determining the availability of exemptions in particular types of eases, even though it might be possible to construe certain of the terms
} 


\section{Provisions Exempting Securities by Reason of the Character of the Issuer}

The provisions of the Act which exempt securities by reason of the character of the issuer are found in Sections $3(a)(2)$ and $3(a)(4)$ to $3(a)(8)$, inclusive. In general they include many types of securities which already enjoy exemption from the application of the various state blue-sky laws. Section $3(\mathrm{a})(2)$ exempts federal, state, and municipal securities, including those of public instrumentalities of the states or territories, those of a person controlled or supervised by and acting as an instrumentality of the federal government, certificates of deposit for any of the securities just mentioned, and also securities issued or guaranteed by national banks or by state or territorial banking institutions which are appropriately supervised and whose business is substantially confined to banking. This provision also exempts securities issued by or representing an interest in or a direct obligation of a Federal Reserve Bank. Section 3(a) (4) exempts securities issued by persons organized and operated exclusively for religious, educational, benevolent, fraternal, charitable or reformatory purposes. Section $3(\mathrm{a})(5)$ exempts generally securities of building and loan associations and farmers' cooperative associations. ${ }^{7}$ Section $3(a)(6)$ exempts securities issued by carriers the issuance of which is subject to approval by the Interstate Commerce Commission. ${ }^{8}$ Section $3(a)(7)$ exempts receivers' and trustees' certificates

found in the exemptive provisions as technical terms. The procedure followed by the Commission in its desire to facilitate operation under the Act has been to authorize its General Counsel, in situations where the inquiry is clearly bona fide and where the Congressional intent as to the meaning of a particular provision seems reasonably clear, to render advisory opinions, the fact that such opinions do not constitute rulings by the Commission being, however, expressly stated. The somewhat limited effect of such opinions in a civil case arising between private litigants is evident. A number of such opinions on matters of general interest have been published, and from time to time there will undoubtedly be further publication of such material.

'The exemption for securities issued by farmers' coöperative associations is limited to such associations as come within the definitions contained in paragraphs (12), (13) and (14) of 5103 of the Revenue Act of 1932. Generally speaking, the definitions set forth in the Revenue Act make the exemption available only to producers' coopperatives having as their chief purpose the marketing of farm produce, the purchasing of supplies and equipment for members, or the financing of normal crop operations. Securities issued by consumers' coöperatives are therefore not within the scope of the exemption.

'Section $3(2)(6)$ of the Act originally exempted "any security isssued by a common carrier which is subject to the provisions of section $20 a$ of the Interstate Commerce Act, as amended." Section 214 of the Motor Carrier Act of 1933, supra note 1, amended $\$_{3}(a)(6)$ to read: "Any secursty issued by a coinmon or contract carrier, the issuance of which is subject to the provisions of section $20 a$ of the Interstate Commerce Act, as amended" (Italies supplied). Prior to this amendment the last clause of this section apparently modified the word "carrier" rather than the word "security." The effect of the amendment seems to have been to remove from the exempt status certain securities issued by carriers. In the first place, the definition of "security" in $\$ 20 a(2)$ of the Interstate Commerce Act, 41 STAT. 494 (1920) 49 U. S. C. $\$ 20 a(2)$, is much narrower in scope than that contained in $\$ 2(x)$ of the Securities Act, applying only to a share of capital stock, bond, or "other evidence of interest in or indebtedness of" a carricr. This definition apparently does not include voting urust certificates or certificates of deposit. Furthermore, $\$ 20 a(9)$ of the Interstate Commerce Act provides specifically that the issuance of certain securities by carriers is not subject to the requirement of approval by the Interstate Commerc. Commission. These are, generally, notes maturing in less than two years in an aggregate amount of not more than $5 \%$ of the carrier's outstanding securities. Carriers are merely required to file a certificate of notification with the Interstate Commerce Commission in respect of such securitics within ten days after their issuance. It is at least doubtful whether the issuance of notes of this character would be construed to be subject to $\$ 20$ within the meaning of $\$_{3}(a)(6)$. In addition, it seems clear that securities issued by motor carriers in a total amount of less than $\$ 500,000$ (including outstanding securities), which under $\$ 214$ of the Motor Carrier 
issued with court approval. Section $3(a)(8)$ exempts insurance and endowment policies and annuity contracts issued by corporations subject to supervision of an insurance commissioner, bank commissioner, or similar state official.

\section{Provisions Exempting Securities by Reason of the Character of the Security or the Issue of Which the Security is a Pakit, Regardless of the \\ Character of the Issuer}

Two sections of the Act afford exemptions in which the basis of the exemption is not the character of the issuer but rather the character of the security itself or of the issue of which it is a part.

Section 3(a) (3) is designed to exempt ordinary commercial paper of the character usually available for rediscount by the Federal Reserve banks. ${ }^{8}$ Specifically, the exemption extends to "any note, draft, bill of exchange, or bankers' acceptance which arises out of a current transaction or the proceeds of which have been or are to be used for current transactions, and which has a maturity at the time of issuance of not exceeding nine months, exclusive of days of grace, or any renewal thereof the maturity of which is likewise limited." The meaning of the term "current transactions," with particular reference to collateral trust notes issued by finance companies, is discussed in a published opinion of the Commission's General Counsel. ${ }^{10}$

Section 3 (b) empowers the Commission, by its rules'and regulations, and subject to such terms and conditions as may be prescribed therein, to exempt, to the same extent as other securities specified in Section 3, any class of securities as to which it finds that by reason of the small amount involved or the limited character of the public offering compliance with the registration provisions is not necessary. This power of the Commission is, however, limited by a provision that no issue of securities shall be so exempted where the aggregate amount at which such issue is offered to the public exceeds $\$ 100,000$. Pursuant to this section the Commission has adopted regulations exempting various types of small issues of securities upon .conditions adapted to the character of the particular types of issues exempted and to the technique ordinarily employed in the distribution of such issues. The regulations thus adopted fall into two categories: regulations relating to securities broadly designated as "oil and gas interests,"11 and regulations relating to securities generally, other than oil and gas.interests.

Act of 1935 are not subject to $\$ 203$ of the Interstate Commerce Act, are not within the exemption from registration provided by $f_{3}(2)(6)$.

"See H. R. Rep. No. 85, 73rd Cong., Ist Sess. (1933) 15. However, comparison with 513 of the Federal Reserve Act, as amended, 12 U. S. C. \$343, indicates that the exemption afforded by $\$ 3(2)(3)$ may be somewhat broader than was intended by Congress.

${ }^{20}$ Securities Act Release No. 401 (June 18, 1935). This opinion supersedes an earlier opinion published in Securities Act Release No. 388 (June 8, 1935).

"The term "security," as defined in $\$ 2(1)$ of the Securities Act, includes any "fractional undivided interest in oil, gas, or other mineral rights," and also any "certificate of interest or participation in 2ny profit-sharing agreement." The several types of oil and gas interests covered by this definition which are embraced within the Commission's exempting regulations are set forth in Rule 300 of the General Rules and Regulations under the Securities Act. As there indicated, the term "security" has been construed to 
The regulations relating to securities other than oil and gas interests are contained in Regulation A of the General Rules and Regulations. ${ }^{12}$ The outstanding characteristic of these regulations is the requirement of the use of a brief prospectus containing specified information with respect to the security offered, and the financial affairs and business of the issuer. This requirement is imposed by the rules relating specifically to shares of stock in a corporation or similar interests in a trust or unincorporated association (Rule 202), first mortgage real estate notes cr bonds of less than $\$ 500$ denomination (Rule 203), certificates of deposit (Rule 204), securities exchanged for outstanding securities or claims (Rule 205), and voting trust certificates (Rule 206); and in the three rules last mentioned the requirement constitutes in substance the only condition of exemption. The limited prospectus requirement is absent only in the broad general exemptions conferred upon offerings of less than $\$ 30,000$ (Rule 200) and upon offerings, of less than $\$ 100,000$ in the case of securities of substantial denominations sold for cash (Rule 20r), and in the specialized exemptions provided for fractional undivided interests in mineral rights other than oil and gas rights (Rule 207), securities issued in certain types of bank reorganizations (Rule 208), and mortgages insured by-the Federal Housing Administrator (Rule 209). Except in the case of Rules 202 and 203 there is no requirement that the prospectus shall be filed with the Commission; and even where such filing is provided for, although the issuer is ordinarily notified by the Commission of any apparent failure to comply with the rule, no approval or other action by the Commission is required to validate the use of the prospectus. ${ }^{13}$

The regulations relating to oil and gas interests ${ }^{14}$ similarly require the filing with the Commission of a modified form of prospectus, known as an offering sheet,

include landowners' royalty interests and also the usual types of interests by the sale of which many smaller oil developments are financed, such as working interests, overriding royalty interests, and oil and gas payments.

${ }^{2}$ Exempting regulations for particular classes of securities were published in Securities Act Releases Nos. 16 (July 27, 1933), 66 (Nov. I, 1933), 89 (Dec. 21, 1933), 122 (Feb. 17, 1934), and 159 (April 27, 1934). These regulations were grouped and expanded in regulations published in Securities Act Release No. 182 (June 29, 1934). Subject to certain revisions and additions made in Securities Act Re. leases Nos. 218 (Aug. 29, 1934), 247 (Oct. 31, 1934), 330 (April 4, 1935), 405 (June 20, 1935), and 532 (Oct. 19, 1935), these regulations were embodied as Regulation $A$ in the General Rules and Regulations, effective March 15, 1936. Rule 201, formerly Part II of Securities Act Release No. 182, was modified by action of the Commission published in Securities Act Release No. 890 (July 10, 1936).

18 At the time of writing, the Commission has under consideration, and has transmitted to state securities commissions and other interested persons for comment, a proposed new regulation repealing the present Regulation A (except possibly as applied to certain special situations), and substituting a regulation pursuant to which exemption depends in general upon compliance with the blue sky laws of the several states in which the securities are sold.

16 These regulations, originally published in Securities Act Releases Nos. I85 (June 30, 1934) and 355 (May 3, 1935), with additions and revisions published in Securities Act Releases Nos. I 88 (July 3, 1934), 206 (Aug. 14, 1934), 223 (Sept. 15, 1934), 239 (Oct. 22, 1934), 279 (Jan. 17, 1935), 297 (Feb. 14, r935) and 390 (June 8, 1935), are now contained in Regulation B of the General Rules and Regulations. Since the effective date of Regulation B (March 15, 1936), substantive changes in the regulations have been effected by regulations published in Securities Act Release No. 833 (June 8, 1936) and minor revisions have been made and published in Securities Act Releases Nos. 983 (Aug. 15, 1936), 1071 (Oct. 7, 1936) and 1098 (Oct. 22, 1936). 
and the delivery of a copy thereof to the purchaser prior to the conclusion of any contract of sale. However, the regulations require further that any such offering sheet shall be effective only for IIo days from the date of the earliest information contained therein, and that it shall be subject to a modified stop-order proceeding analogous to that provided for by Section $8(\mathrm{~d})$ of the Act with respect to registered securities.

The peculiar character of oil and gas interests goes far to explain the difference between the treatment accorded to such interests under the Commission's regulations and that accorded to other types of securities. Unlike the normal issuer, the person who, for the purposes of the Act, is the issuer of an oil or gas interest usually retains no participation in the control of, or in the profits from, the property to which the interest relates. Similarly, the purchaser of such an interest, as a practical matter, seldom is in a position to exercise any voice in the management of such property. It follows that there is usually lacking any such continuing legal relationship between issuer and security holder as obtains in the case of ccrporate enterprise. In addition, although producing royalties in proven fields are undoubtedly made the subject of conservative investment by substantial corporations and others having the special knowledge requisite to enable them to appraise intelligently their value, there are peculiar hazards in the purchase of oil or gas interests, whether producing or nonproducing, by an investor who, although of reasonable intelligence, lacks such knowledge. Under these circumstances, it is not surprising that, although the Commission deemed it wise, by the exercise of its exemptive power, to free from the registration requirements the many offerings of small "issues" of oil and gas interests making up the great bulk of such interests publicly offered, ${ }^{16}$ it hedged about with certain special safeguards the exemption from registration which it afforded, ${ }^{16}$ and appropriately limited the life of such exemption so as to prevent an oil or gas interest, the value of which may obviously be subject to rapid fluctuation because of changing conditions in the underlying properties, from retaining an exempt status indefinitely on the basis of information which in its nature is likely rapidly to become obsolete.

Provisions Exempting Securities by Reason of the Manner of Their Distribution, Regardeess of the Character of the Issuer, the Security, or the Issue of Which IT IS A PaRT

The exemptive provisions of the Securities Act falling within this classification are contained in Sections $3(a)(9)$, relating to securities exchanged by the issuer with its existing security holders, 3 (a) (ro), relating to securities exchanged in the process

\footnotetext{
${ }^{15}$ In more than three years of operation under the Securities Act only three registration statements covering oil and gas interests (excluding investment trusts of such interests) have been filed with the Commission.

${ }^{20}$ Despite the imposition of the special safeguards indicated in the text, the Commission by regulation has relieved the person who sells an exempt oil or gas interest to a professional buyer from compliance with the prospectus requirements, although in the case of such a sale to a non-resident the filing of 2 report of such sale is required. See Rule 320, as amended by action of the Commission published in Securities Act Release No. I07I (Oct. 7, 1936).
} 
of a reorganization under the supervision of a court or an appropriate administrative body, and 3(a)(II), relating to securities forming part of an issue distributed exclusively to residents of the state of the issuer's residence or incorporation. In addition, Sections 77 and $77 \mathrm{~B}$ of the Bankruptcy Act each contain provisions relating to the exemption of securities issued in reorganization proceedings under those sections.

\section{(1) Securities Exchanged with Existing Security Holders (Section 3(a)(9))}

The first drafts of the Securities Act provided an exemption for. "the issuance of securities to the existing security holders or other existing creditors of a corporation in the process of a bona fide reorganization of such corporation made in good faith and not for the purpose of avoiding the provisions of this Act, either in exchange for the securities of such security holders or claims of such creditors or partly for cash and partly in exchange for the securities or claims of such security holders or creditors." "17 In addition, these drafts provided an exemption for the issuance and delivery "of any security in exchange for any other security of the same issuer pursuant to a right of conversion, entitling the holder of the security surrendered in exchange to make such conversion: Provided, That the security so surrendered has been registered under the law or was, when sold, exempt from the provisions of the law." 18 In the course of consideration of the bills in Committee, the Senate eliminated both of the quoted provisions, and the House eliminated the second and amended the first by substituting the words "under the supervision of any court" for the words "made in good faith and not for the purpose of avoiding the provisions of this Act." 18 Thus, in the different bills originally passed by the Senate and House, provision was made for the exemption of intra-corporate readjustments only in cases where such readjustments were effected under court supervision.

Section 4(3) of the Act as finally passed retained this latter provision and also exempted the "issuance of a security of a person exchanged by it with its existing security holders exclusively, where no commission or other remuneration is paid or given directly or indirectly in connection with such exchange."20 At the time of the amendment of the Act in 1934 this provision was replaced by Section 3(a) (9),

${ }^{17}$ S. 875, 73rd Cong., Ist Sess. (1933) $\$ 12$ (d); H. R. 4314, 73rd Cong., Ist Sess. (1933) \$12(d).

${ }^{18} \mathrm{~S}$. 875, supra note $17, \$ 12(f)$. The same provision appeared in H. R. 4314, supra note 17, except that the word "issue" was used in place of the word "issuer," presumably by reason of a typographical error.

19 In reporting upon this change, the House Commitiee stated that:

"This paragraph also exempts the distribution of securities during a bona fide reorganization of a corporation when such reorganization is carried on under the supervision of a court.

"Reorganizations carried out without such judicial supervision possess all the dangers implicit in the issuance of new securities and are, therefore, not exempt from the act. . ." H. R. REP. No. 85, 73rd Cong., Ist Sess. (1933) 16.

The report of the Conference Committee upon this section contains the following comment:

"The Senate agreed that the mere exchange with its security holders of one form of security for another by an issuer where no commission or other remuneration is paid, shall be exempt. This exemp. tion is considered necessary to permit certain voluntary readjustment of obligations. Inasmuch as any exchange that involves the payment of a commission of any sort is not exempt, there is no danger of the provision being used for purposes of cvasion." H. R. (CoNF.) REP. No. 152, 73rd Cong., 1st Sess. (1933) 25 . 
which exempted any security "exchanged by the issuer with its existing security holders exclusively where no commission or other remuneration is paid or given directly or indirectly for soliciting such exchange."

Section $3(a)(9)$, in contradistinction to Section $3(\mathrm{a})(\mathrm{Ir})$, contains no language expressly limiting the exemption to securities forming "part of an issue" the whole of which is sold as specified in the exempting provision. At first reading, therefore, Section 3(a) (9) appears to confer exemption upon any security exchanged with the issuer's existing security holders, even though other securities of the same class, as a part of the same general plan of financing, are sold to others than existing security holders, or to existing security holders otherwise than by way of exchange. Such a construction, however, gives insufficient weight to the use of the word "exclusively," as employed both in Section 3(a)(9) and in its predecessor, Section 4(3). In neither section is the grammatical function of the word entirely clear; but in order to avoid an interpretation which would reject the word as pure surplusage, it appears necessary to adopt the view that the exemption is available only to securities constituting part of an issue which, as a whole, is exchanged in conformity with the requirements of the section. ${ }^{21}$

This conclusion appears to be supported by the legislative history of Section $3(\mathrm{a})(9)$. In connection with the amendment of the Securities Act.by Title II of the Securities Exchange Act of 1934, the substitute for the first clause of Section 4(3) proposed in H. R. 9323 provided exemption for "any security issued by a person where the issue of which it is a part is exchanged by it with its own security holders exclusively. ....". The proposed amendment was altered in conference so as to eliminate the reference to the "issue" of which the security was a part; but it appears from the statement of the Managers on the part of the House in the Conference Report that the changes in the proposed Section 3(a)(9) made in conference were "intended only to clarify its meaning." "'3

Nor does this view appear in any way to conflict with the purpose of the exemption. The exemption cannot be supposed to evidence a legislative presumption that existing security holders as a class are in no need of the protection afforded by the registration and prospectus requirements of the Act; such an assumption, besides being at variance with common experience, was expressly negatived in one of the early reports on the bill.24 Rather, in view of the expressed disinclination of Congress to exempt the issuance of securities in voluntary reorganizations, the final in-

${ }^{21}$ For a discussion of the meaning of the word "issue," as used in $\$ 3(a)(11)$. see p. I10, infra.

20 The purpose of the amendment is described in the Conference Report on the Securities Exchange Act as follows:

"The amendments adding new sections $3(a)(9), 3(a)(10)$, and $3(a)(11)$ are based upon sections $4(3)$.nd $5(c)$ of the original act. which are proposed to be repealed. By placing these exemptions under section 3 it is made clear that sccurities entuted to exemption on original issuance setain their excmption; if the issuer is not obliged to register in order to make the original distribution, dealers within a year are subject to no, restriction against dealıng in the securities. The result is in line with the Commission's interprctation of the act as it stood beforc, but the amendment removes all doubt as to its correctness." H. R. (Conf.) Rep. No. 1838,73 rd Cong., 2nd Sess. (1933) 40.

$\approx$ Ibid.

ssee note r 9 supra. 
clusion of a provision exempting the issuance of such securities upon specified conditions would appear to rest on a balancing of interests between the corporation and its security holders, and to indicate a recognition that the burden of delay and expense involved in registration might well be disproportionately heavy in a purely intracorporate readjustment where the very fact of the readjustment would tend in the majority of instances to indicate an embarrassed financial condition. In such cases, it may be supposed, the interest of the security holders in being afforded full information as to the corporate affairs is made to yield to their interest, in common with the issuer itself, in expeditious and economical readjustment. Where, however, a portion of the issue is to be disposed of under circumstances in any event requiring registration, the interest of the issuer in securing exemption for the portion of the issue exchanged with its security holders becomes an interest merely in postponing registration until after completion of the exchange. Such an interest, although occasionally of undoubted practical consequence to the issuer in its negotiations for the underwriting of the portion of the issue not taken up by security holders under the exchange offer, would not seem of sufficient weight to justify the issuer in depriving its own security holders of information which, as part of the same general transaction, is to be made available to other members of the investing public.

In some instances, of course, the point can be made that the interpretation suggested above may result not in merely delaying the making of an exchange offer until after the effectiveness of a registration statement which would in any event be required before the offering to the public, but in necessitating a registration which otherwise would not be required at all. Thus, it might be contended that Section $3(a)$ (9) should be so construed as to permit an issuer to make an exchange offer to its security holders under cover of Section 3(a) (9), and then to claim exemption for the unexchanged balance of the issue where it is sold to others than security holders, upon terms meeting the requirements of Section 3 (a)(II), the second clause of Section 4(I), or the Commission's rules promulgated pursuant to Section 3(b). This contention, however, neglects the correlative problem of interpretation arising under the provisions by virtue of which exemption for the unexchanged balance is thus sought. Even though Section 3(a) (9) were interpreted as exempting such securities as were actually exchanged, it is believed that none of the provisions under which exemption would be claimed for the unexchanged balance could by its terms properly be applied to an offering of securities where as a part of the same general financing transaction other securities of the same class had been or were concurrently sold otherwise than in accordance with such terms.

A second problem of interpretation under Section 3(a)(9) relates to the application of that section to "conversions," i.e., to exchanges effected pursuant to a right of exchange originally issued with, or as an incident of, the security to be surrendered in exchange. The language of Section $3(a)(9)$ itself appears clearly to encompass exchanges of such a type no less than exchanges involved in corporate 
readjustments initiated by the issuer; and any policy favoring exemption of the latter would appear to apply with equal or greater force to the former. Nevertheless, considerable question has been raised by the language of the last sentence of Section 2(3), relating to the definition of the term "sale."25 From this language, providing in effect that the issuance of a security pursuant to a delayed conversion right is not to be deemed a sale until such conversion right is exercised, and by implication that the issuance of a security with an immediately exercisable conversion right is to be deemed an immediate sale of the security issuable upon conversion, it is argued that the offering of a security carrying with it a conversion right involves an offering of the security issuable upon exercise of such conversion right as part of the consideration paid for the security initially offered. To include a conversion within the operation of Section $3(a)(9)$, it may be argued, would be inconsistent not only with the purpose of Section $2(3)$, but with its express words. This view, which receives substantial support from the House Report on H. R. $5480,{ }^{20}$ was publicly adopted by the Federal Trade Commission in Release No. 97, in which it was stated that the issuance of bonds immediately convertible into stock "will involve an offer of the stock which will require immediate registration of the latter", and that a "fee for the registration of the stock will, of course, have to be paid as well as for the bonds."

Notwithstanding the statement of the House Committee referred to above, the writers are of the opinion that the position taken by the Federal Trade Commission in Release No. 97 is open to serious question. The term "sale," as defined in the first clause of Section 2(3), it should be noted, is of ample breadth to cover a disposition by way of exchange; and, properly viewed, the last sentence of that section appears to do no more than to emphasize the fact that an exchange upon exercise of a conversion right is to be regarded as a "sale," and to fix the time as of which such "sale" shall, for the purposes of the registration requirements of the Sscurities Act, be deemed to occur. Thus, it may be recognized that a sale of an immediately convertible security constitutes an immediate "attempt or offer to dispose of," and so a "sale" of, the security issuable upon conversion, without in any way disregarding the fact that the disposition attempted is by way of exchange for the original convertible security, and that the security so disposed of is therefore susceptible of exemption under Section 3(a) (9).

s "The issue or transfer of a right or privilege, when originally issued or transferred with a security, giving the holder of such security the right to convert such security into another security of the same issuer or of another person, or giving a right to subscribe to another security of the same issuer or of another person, which right cannot be exercised until some future date, shall not be deemed to be a sale of such other security; but the issue or transfer of such other security upon the exercise of such right of conversion or subscription shall be deemed a sale of such other security."

$x$ "This [provision in section $2(3)$ ] makes it unnecessary to register such a security prior to the time that it is to be offered to the public, although the conversion right or the right to subscribe must be registered. When the actual securities to which these rights appertain are offered to the public, the bill requires registration as of that time. This permits the holder of any such right of conversion or warrant to subseribe to judge whether upon all the facts it is advisab!: for him to cxercise his rights." $H$. $R$. ReP. No. 85, 73rd Cong., Ist Sess. (1933) i2. 
Nor does it appear that the view suggested has the result of rendering supererogatory any of the language of Section 2(3). That section, in relation to conversions and subscriptions, envisages eight different types of situations, in two, and only two, of which can the time of the "sale" be rendered immaterial by applying Section 3 (a) (9) to sales by way of conversion; ${ }^{27}$ and even in these two situations-the cases of an immediate and of a delayed conversion right involving securities of the same issuer-the time of "sale" becomes immaterial only if the conditions of Section 3(a) (9) are complied with. If, for example, an issuer were to pay commissions for soliciting the exercise of the conversion privilege, and were thus to deprive itself of exemption under Section 3(a) (9) for the securities issuable upon such conversion, the provisions of Section 2(3) would be of material bearing in requiring registration of such securities and in determining the time at which such registration would be -required.

In the view of the writers, therefore, securitics carrying with them rights to convert immediately or at some future date into other securities of the same issuer may, if themselves registered under the Securities Act, be offered and sold without registration of the securities issuable upon such conversion, provided that the conditions of Section $3(a)(9)$ are observed with respect to the securities so issuable upon conversion..$^{28}$

Still a third problem not infrequently arising under Section $3(a)(9)$ involves the construction of the words "exchanged by the issuer with its existing security holder". This language, it will be noted, does not in terms require that the securities surrendered in exchange for the new securities shall be securities of the same issuer, nor even that the exchange be one of security for security, but merely that the transaction shall be by way of "exchange" and shall be with persons who at the time of the exchange are security holders of the issuer of the new securities. However, to give to the term "exchange" its broadest possible sense, which might cover the issuance of securities for other species of property, or even for cash, would clearly extend the operation of the section beyond its contemplated bounds; and some limitation must therefore be found appropriate to the purpose sought to be accomplished. In the light of the legislative history and evident purpose of the section, it seems necessary

I A security holder may have (I) an immediate right to convert into securities of the same issuer, (2) a postponed right of the same nature, (3) an immediate right to convert into securities of a different issuer, and (4) a postponed right of the same nature. Four similar situations may exist with reference to rights to subscribe to securities.

Although, contrary to the practice originally followed by the Federal Trade Commission, the payment of a double filing fee in connection with the registration of convertible securities is no longer required, the question discussed in the text may be of substantial importance in cases where the securities initially sold are entitled to some exemption which would not extend to the securities into which such initial securities are convertible-e.g., where the initial securities are sold in conformity with the conditions of $\$_{3}(a)(11)$, or are sold in compliance with some rule under $\$ 3(b)$ which by its terms is inapplicable to the type of securities into which such initial securities are convertible. Furthermore, even in cases in which the initial securities are registered under the Securities Act, the question may become important in determining the necessity of delivering a prospectus with the security issued upon conversion, or, in the case of 2 postponed conversion right, in determining the necessity of filing a separate registration statement when such right becomes exercisable. 
as a matter of interpretation to regard the language as affording an exemption only when the exchange conducted by the issuer of the new securities with "its security holders" involves the surrender to such issuer of securities issued by it. ${ }^{29}$

Even under this construction, however, the application of the section may be far from clear in particular cases. For example, the original issuer of bonds may have disposed of the property securing such bonds to another person, and may for many years have had no connection with such property, or may, if a corporation, be no longer in existence. Can the present owner of the mortgaged property, desiring to offer new bonds in exchange for the bonds outstanding, be regarded as engaged in an exchange with "its existing security holders"? If at the time of the transfer of the property liability on the bonds was assumed by the new owner, there is little difficulty in regarding such new owner as the issuer of the outstanding bonds; and in such a case the exemption would seem to be available. In the absence of a past bona fide assumption of liability, however, the issuer of the new securities can in no strict sense be regarded as the issuer of the old, and the exemption, if it is to be available, must be rested upon a view that security holders may be the security holders "of" a person other than the actual issuer. Such a concept, although perhaps consistent with the rather loose language of Section $3(a)(9)$, seems difficult to support with legal learning. ${ }^{30}$

No discussion of the problems of construction raised by the language of Section 3 (a) (9) would be complete without at least a reference to the question of the application of the exemption to securities issued in transactions which, although framed to fall within the language of the section, have for their purpose the raising of new capital by the sale of securities to the public without registration under the Act, and the question of the continued application of the exemption to securities which, originally issued in compliance with the conditions of Section $3(a)(9)$, are subsequently made the subject of a secondary distribution to the public by controlling interests through the medium of an underwriter. Some consideration of these questions is found in the opinion of the Commission's General Counsel published in Securities Act Release No. 646.

From a practical point of view, there is probably little doubt that for the majority of issuers the problems of legal analysis discussed above under this heading yield in importance to the problem of determining the types of "commission or other remuneration" the payment of which will operate to defeat the exemption. Prior

*Although the payment of any cash by the security holder as part of the consideration for the new securities would defeat the exemption, Rule 150 of the General Rules and Regulations, defining the phrase "commission or other remuneration" as used in $\$ 3(a)(9)$, embodies the view that the exemption is not affected by the fact that the exchange offer may include an offering of cash by the issuer in partial consideration for the securities surrendered. To the extent that cash is paid by the issuer, the issuer is buying, rather than selling, securities.

${ }^{2}$ Limitations of space prevent diseussion of the correlative problems arising in connection with securities of joint issuers, and with guaranteed securities. The difficulty of the latter problem will be apparent when it is recalled that a guarantee of a security, under the definition in $\$ 2(\mathrm{I})$ of the Act, is itself to be regarded as a separate security issued, of course, by the guarantor. 
to the substitution of Section 3(a) (9) for Section 4(3), the exemption was dependent upon absence of any payment of remuneration "in connection with" the exchange. However, to have construed that language as covering all payments made in connection with the exchange would in substance have rendered the exemption inoperative, as all exchanges must call for some measure of remuneration, at least for routine and mechanical services. The obvious impracticability of the restriction in its literal application was recognized in the amendment, and the words "for soliciting" were substituted for the words "in connection with." 31 Under the revised language, it is clear that remuneration for purely mechanical services, or even for services which though not mechanical are in their nature ancillary to the effective mechanical operation of the transaction (such as the services of attorneys or other experts employed to prepare the forms of resolutions, letters to stockholders, or published advertisements), would have no effect upon the availability of the exemption; the broad line is to be drawn at remuneration for services involving active solicitation and promotion, and especially at remuneration the payment of which is contingent upon the success of the solicitation or promotion. Every exchange transaction can of course evoke borderline cases; but in outline the problem is simple, and as a matter of discussion is susceptible only of an empirical treatment impossible within the limits of this article.

(2) Securities Exchanged in the Process of Reorganization under the Supervision of a Court or an Appropriate Administrative Body (Section 3(a)(10); Bankruptcy Act, Sections $77(f)$ and $77 B(h))$

There is no realm in which it is possible to find more variants from the orthodox procedure of security distribution than in the process of reorganization. Furthermore, the sponsors of a particular reorganization plan may find it difficult to cull from the records of a financially involved debtor information which is sufficiently instructive and authentic to be of value to those to whom such plan is proposed. It was perhaps with these considerations in mind that the framers of the Act and of the reorganization sections of the Bankruptcy Act determined that, to the extent that judicial supervision could be availed of to afford some guiding restraint against overreaching by those in strategic positions, it would be wise to relieve of the demands of registration the already intricate reorganization process.

To consider exhaustively the problems which inevitably arise in the application of those provisions exempting securities issued in the course of reorganization, would require extensive treatment. Furthermore, the Commission's present study, pursuant to Section 211 of the Securities Exchange Act of 1934, of the activities and functions of protective and reorganization committees will presumably eventuate in such a re-examination of the whole procedure now afforded for the protection of the

$n$ In effecting this amendment, Congress followed the Federal Trade Commission's liberal interpretation of the original text. See letter from Baldwin B. Bane, Chief of Securities Division, printed in Paentice-Hali-Securities Regulation Service, Vol. I, \$3890-D; Commerce Clearing House, Stocks AND BONDS LAw SERvice, Vol. III, par. 2161.03. 
investor-in-reorganization as to make of doubtful value any detailed consideration of any peculiar problems of exemption which such procedure now presents. The writers are therefore limiting their consideration of the exempt status of securities issued in reorganizations to a summary of the origin and extent of the present provisions of law and to a brief reference to certain general problems.

Section 3(a) (ro) of the Act provides for the exemption of:

"Any security which is issued in exchange for one or more bona fide outstanding securities, claims or property interests, or partly in such exchange and partly for cash, where the terms and conditions of such issuance and exchange are approved, after a hearing upon the fairness of such terms and conditions at which all persons to whom it is proposed to issue securities in such exchange shall have the right to appear, by any court, or by any official or agency of the United States, or by any State or Territorial banking or insurance commission or other governmental authority expressly authorized by law to grant such approval; ..."

This section, which was included in the 1934 amendments to the Act, had its origin in Section 4(3) of the Act, which provided generally for the exemption of the issuance of securities exchanged in the process of a bona fide reorganization, provided that such reorganization was effected under judicial supervision. ${ }^{32}$

The transfer of this exemption from the category of "Exempted Transactions" (Section 4) to that of "Exempted Securities" (Section 3) was occasioned by the same considerations which brought about the substitution of Section $3(a)(9)$ for the first clause of Section 4(3)..$^{33}$ But Section 3(a)(ro) did more than alter the character of the exemption. It required more careful scrutiny of the reorganization plan by substituting for the former loose requirement of "supervision" a requirement that the fairness of the terms and conditions of the exchange be approved after an appropriate hearing; on the other hand, it extended the class of tribunals whose approval would suffice to include federal officials and agencies and "any State or Territorial banking or insurance commission or other governmental authority expressly authorized by law to grant such approval."

Increased immunity from registration was afforded by the enactment of the corporate reorganization section of the Bankruptcy $\mathrm{Act}^{34}$ on the day following the signing by the President of the Securities Exchange Act of 1934, Title II of which consisted of the 1934 amendments of the Securities Act of 1933 . In general, the exemption afforded by subdivision (h) of Section $77 \mathrm{~B}$ extended to all securities issued pursuant to plans confirmed under that section, and, subject to certain qualifications referred to below, to certificates of deposit issued in proceedings under that section.

The exemptive provisions of Section ${ }_{77} \mathrm{~B}$ were, of course, unavailable in reorganization proceedings involving railroad corporations subject to Section 77 of the Bankruptcy Act. It is therefore not surprising to find this latter section amended

2 See p. 96, supra.

4 48 Strat. 9 I I (1934), 1 I U. S. C. 5207 (1934).

* See note 22, supra. 
on August $27,1935{ }^{35}$ to provide for an exemption comparable to that found in Section $77 \mathrm{~B}(\mathrm{~h})$. To a large extent, the securities thus exempted were already exempt from the registration and prospectus requirements of the Securities Act by virtue of Section $3(a)(6)$. However, Section $77(f)$ was so comprehensive as to include certain securities such as voting trust certificates, certificates of deposit and short-term obligations, apparently not within Section 3(a)(6). Furthermore, it is possible that the effect of this amendment was to provide a more complete exemption from the provisions of the Securities Act for those securities already within Section $3(a)(6) .^{30}$

There is, on the whole, relatively little difficulty in asc' $t$ taining whether, at the time of issuance of a security in a reorganization under judicial or administrative supervision, the conditions requisite to its exemption have been satisfied. However, questions frequently arise as to whether securities which are proposed to be issued pursuant to a plan of reorganization may be offered as exempt securities, either directly in exchange for the old or by means of the solicitation of the deposit of the old securities in anticipation of such exchange, prior to the satisfaction of.the conditions of the exemption upon which reliance is placed. On this score Section $77(f)$, applying to the reorganization of interstate railroad corporations, is the most clearcut. It exempts (I) all securities issued pursuant to any plan of reorganization confirmed by the court, (2) all securities issued by the debtor or by the trustee or trustees in the nature of receivers' certificates, and (3) all certificates of deposit representing securities of, or claims against, the debtor, except for those issued by com. mittees not subject to the jurisdiction conferred upon the Interstate Commerce Commission by subdivision ( $\mathrm{p}$ ) of Section 77. Since the jurisdiction conferred by subdivision ( $p$ ) extends (with certain minor exceptions) to the solicitation, during the pendency of proceedings under that section or of any state or federal receivership proceedings, of the deposit of securities, and to any use of proxies, authorizations or deposited securities in such proceedings, even though obtained prior to the institution of -such proceedings, it is evident that except to the extent that there may be a solicitation, prior to the institution of such proceedings, of the exchange or deposit of outstanding securities, Section $77(\mathrm{f})$ relieves the issuer and all committees from the necessity of registration. ${ }^{37}$

As regards the status of the securities ultimately issuable under the plan and interim securities in the nature of receivers' certificates, Section $77 \mathrm{~B}(\mathrm{~h})$ affords an exemption in respect of non-carrier securities substantially coextensive with that afforded by Section $77(f)$; and it would seem that, to the extent that the solicitation of approvals or acceptances of the plan may involve any offering of such securities, such offering is an offering of exempt securities. In prescribing the modus operandi by which new securities are to emerge from the reorganization chrysalis, each

${ }^{35} 49$ STAт. 9 I I (1935), I I U. S. C. \$205. $\quad$ So See note 4, supra.

27 If the original issuer, even prior to the institution of proceedings, seeks the deposit of outstanding securities to evidence the assent of the holder to accept new securities of the same issuer, either in $\$ 77$ proceedings or otherwise, the certificates of deposit, as well as the securities ultimately to be issued, would, in the absence of paid solicitation, be exempt under $\$_{3}(a)(9)$. 
section implicitly contemplates the submission of a plan to the old security holders; and the exemption from registration afforded to such securities would be a hollow form if the solicitation of the requisite approvals and acceptances could not be engaged in without registration. As regards certificates of deposit representing securities of the debtor, however, Section $77 \mathrm{~B}(\mathrm{~h})$ apparently limits more narrowly the scope of the exemption than does Section $77(f)$. The exemption afforded by the former section extends to: "All securities issued pursuant to any plan of reorganization confirmed by the court in accordance with the provisions of this section, including, without limiting the generality of the foregoing, any securities issued pursuant to such plan and securities issued by the debtor or by the trustee or trustees pursuant to subdivision (c), clause (3), of this section. and all certificates of deposit representing securities of or claims against the debtor which it is proposed to deal with under any such plan" (italics supplied). Whatever may have been the unexpressed intention of its proponents, this provision is obviously open to the construction heretofore given it by the Commission's General Counsel to the effect that the exemption afforded to certificates of deposit is limited to those issued in respect of securities with which it is proposed to deal under a previously confirmed plan. ${ }^{38}$ However, despite this interpretation of Section ${ }_{77} \mathrm{~B}(\mathrm{~h})$, the General Counsel's opinion recognized that, even without registration or prior confirmation of a plan, deposit receipts might be issued or securities might be stamped, provided that the issuance of receipts or the use of the stamping device dues no more than evidence the security holder's approval or acceptance of a plan to be consummated only in Section $77 \mathrm{~B}$ proceedings. The effect of this is that, unless some other exemption is available for its certificates of deposit, a committee may not, without the prior registration of its certificates, solicit the deposit of securities under a deposit agreement giving to it power to pledge or deal freely with the deposited securities or to bind the depositors to a modified plan, either in the exercise of the committee's absolute discretion or because of the security holder's failure to dissent. ${ }^{39}$

It thus appears that, subject to certain restrictions, the securities which it is proposed to issue only pursuant to a plan confirmed, prior to such issuance, in a Section 77 or Section $77 \mathrm{~B}$ proceeding, may in effect be offered to the old security holders and creditors in advance of the date of confirmation. It is doubtful, however, whether a comparable conclusion is justified in those reorganizations in which Section $3(\mathrm{a})(\mathrm{ro})$ is relied upon to exempt securities issued in settlement of outstanding

${ }^{28}$ Sec Securities Act Release No. 296 (Fcb. 15, 1935).

25 Where its jurisdiction permits, a tribunal may of course, in a procecding mecting the requirements of $\$_{3}(a)(10)$, approve the fairness of the terms and conditions of a deposit agrecment giving broad authority to a committee, and after such approval the committce may solicit deposits without registration, at least until such time as it secks, hy promulgation of a plan. to bind existing or future depositors to a proposed ultimate cxchange of securities. In considering the necessity of registration in reorganizations. there should be kept in mind the fact that transactions by persons other than an issuer, underwriter or dealer are exempt, and that, under Rule 3 of the Commission's Rules as to the Use of Form E-I, no sale is snvolved in the submission of a plan of reorganization if the security holder retains or is given a right subsequently to withdraw which is conditioned, if at all, only upon payment of not more than his proportionate share of expenses. 
securities, claims or interests. Prior to the amendment of the Act in 1934, the provision comparable to Section 3(a)(10) required that the issuance of securities be "in the process of a bona fide reorganization of such corporation under the supervision of any court." The substituted provision not merely required judicial or administrative supervision, but also required that the terms and conditions of issuance and exchange be approved "after a hearing upon the fairness of such terms and conditions at which all persons to whom it is proposed to issue securities in such exchange shall have the right to appear" (italics supplied). The purpose of this change, as indicated by the report of the Conference Committee, was to deprive security holders' committees of the "opportunity of obtaining exemption under this section if they secure and exercise an exclusive right to appear for their depositors at hearings on plans of reorganization." 10 Although the implications of this statement are not entirely clear, it seems reasonable to assume that Congress intended to preserve to security holders represented by committees not merely an opportunity to talk in a hearing before the tribunal considering the fairness of a proposed plan, but also an opportunity to exercise a power of choice in the light of the clash of interests finding expression at such hearing. Certainly, in the absence of legislative or judicial clarification of this point, it would seem advisable for sponsors of a reorganization plan, in any solicitation conducted prior to the granting of the judicial or administrative approval upon which exemption under Section $3(\mathrm{a})$ (xo) depends, to limit their activities to the soliciting from security holders of non-binding approvals of the proposed plan, leaving those solicited in a position where they will become bound to the plan only upon affirmative acceptance subsequent to the granting of such judicial or administrative approval.

As regards the extent of the jurisdiction required of the tribunal whose approval is sufficient to confer exemption under Section $3(\mathrm{a})$ (ro), the condition of the section that the tribunal be "expressly authorized by law to grant such approval" is clearly inapplicable to courts and federal administrative agencies, and may also be inapplicable to state banking and insurance commissions. Section 3(a)(10), however, is not an empowering provision, and Congress can hardly have contemplated that the approval of a court or administrative agency would serve as a substitute for registration unless such court or agency were acting within its jurisdiction. A study of the jurisdiction of courts and administrative bodies to give the requisite approval has recently been made, ${ }^{11}$ and accordingly, important as this matter is, the writers have deemed it unnecessary to do more than refer to the problem in this article.

Other questions arising under this section which have received consideration in published opinions of the Commission's General Counsel relate to the necessity of the giving of some adequate notice to those to whom the issuance of securities is proposed, the scope of the "express authorization" required in order to afford a state

${ }^{\circ}$ H. R. (Conf.) Rep. No. 1838, 73rd Cong., 2nd Sess. (1934) 40.

"See Comment (1936) 45 YaLE L. J. 1050, on "Effect of Section 3(2)(10) of the Securities Act as a Source of Exemption for Securities Issued in Reorganizations." 
or territorial governmental authority the dispensing power granted by Section 3 (a) (10), and the nature of hearing which must precede the requisite approval. ${ }^{42}$

One further point requires notice. Reference has already been made to the question whether the exemption afforded by Section $3(a)$ (9) continues when securities originally issued in compliance with its conditions are subsequently made the subject of a secondary distribution to the public through the medium of an underwriter. ${ }^{43}$ The question is equally pertinent in the case of securities exempted by the provisions of Section 3(a) (10), and, as in the case of securities exempt under Section 3 (a) (9), a careful consideration of the legislative history and the apparent purpose of the section supports the view that securities issued in a Section 3(a)(10) exchange should be registered before their public distribution by controlling interests through an underwriter. ${ }^{14}$ Although the adoption of a similar construction of the exemptive clauses of Sections $77(\mathrm{f})$ and $77 \mathrm{~B}(\mathrm{~h})$ could not rest upon the same historical grounds, it is believed that a similar construction of those clauses is justified upon a fair consideration of the evident reason for the exemption thereby provided.

\section{(3) Intrastate Issues (Section 3(a)(II))}

The Securities Act, as originally introduced, dealt with the problem of the intrastate sale of securities by prohibiting the use of the mails and instruments of transportation and communication in the offering, sale and delivery of unregistered securities only when such transactions were effected "in interstate commerce."45

The Act as finally adopted, on the other hand, although prohibiting generally any use of the mails or instrumentalities of interstate commerce in the sale of securities, restricted the broad sweep of this prohibition by the following limitation:

"The provisions of this section relating to the use of the mails shall not apply to the sale of any security where the issue of which it is a part is sold only to persons resident within a single State or Territory, where the issuer of such securities is a person resident and doing business within, or, if a corporation, incorporated by and doing business within, such State or Territory." 18

"Securities Act Release No. 312 (March 15, 1935). "See pp. I0I-102, supra,

"It has been suggested that, in the case of securities exempted under $5_{3}$ (2) (10), different considerations obtain than in the case of securities exempted under $\$ 3(a)$ (9), because of the added protection afforded to the investor by the subjection of the original issuance to judicial or administrative approval. To this suggestion there are at least two answers. First, it is specifically stated in the Conference Report on the 1934 amendments that the same considerations prompted the placing in 53 of the provisions substituted for $\$ 54(3)$ and $5(\mathrm{c})$. (See note 22, supra). Second, although in granting its approval in a proceeding meeting the requirements of $5_{3}(2)(10) 2$ court or administrative agency may give some consideration to the soundness of the new financial structure, its primary concern is normally with the relative treatment of the competing classes of old security holders-a matter which is cf relatively little consequence to future purchasers of securities issued in the reorganization.

${ }^{\circ}$ H. R. 4314, 73rd Cong., ist Sess. (1933) 53a, made it unlawful for "Any person to make use of the United States mails or any means or instruments of transportation or communication to offer in interstate commerce securities other than those issued by a foreign government or subdivision thereof, for sale or to solicit or accept offers to buy such securities in such commerce;" (Italics supplied).

Similar restrictions are found in the prohibitions of $55_{3}(b)$ and $3(c)$ of the same bill, relating to the advertising and to the transmission, respectively, of unregistered securities, and in the equivalent sections of the bill introduced in the Senate (S. 875).

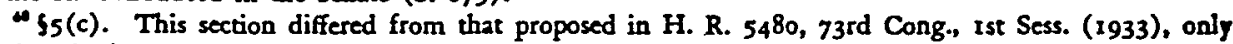
in that the latter exempted also issues sold to residents of the District of Columbia. 
In commenting upon the substantially identical provision of H. R. 5480, the House Committee on Inteistate and Foreign Commerce observed that: "Section 5 (c) also exempts sales within a State of entire issues of local issuers." ${ }^{\text {"77 }}$

Although the provision originally proposed clearly avoided any jurisdictional difficulties, the rejection of that provision, and the substitution of a concept of exemption based upon the intrastate character, not of individual transactions, but of the general plan of financing of which such individual transactions formed a part, indicate an appreciation by Congress of the practical as well as the constitutional limitations upon federal supervision of small-scale, local financing, to which the ordinary methods of high-pressure distribution are largely inappropriate, and in which the opinion of the community may frequently afford a substitute for the registration process.

The provision finally adopted was both narrower and broader than the provisions of the original bill: narrower, in that it required registration as a condition of the use of the mails even for intrastate transactions, unless such transactions formed part of an essentially local distribution; broader, in that for securities forming part of an issue distributed exclusively to residents it pcrmitted the use of the mails without as well as within the state of such residence.

By Title II of the Securities Exchange Act of 1934, Section 5(c) of the Securities Act was repealed, and in its place was substituted Section 3(a)(Ir), exempting any security "which is a part of an issue sold only to persons resident within a single State or Territory, where the issuer of such security is a person resident and doing business within, or, if a corporation, incorporated by and doing business within, such State or Territory." Since the mails could, under the Act prior to amendment, be used on an interstate basis for the distribution of an entire issue to residents, the only material effect of the amendment was to permit the use also of the instrumentalities of interstate commerce for the same purpose. ${ }^{48}$ Consequently, the discussion under this heading may be regarded as applying with equal force to Section 5(c) and to Section 3(a)(II).

Perhaps the most serious question of construction under Section 3(a)(II) relates to the meaning of the words "sold only to persons resident." Read literally, Section 3 (a)(II) would confer exemption on an issue of securities sold by the issuer to one or more residents, even though the purchasers intend to and in fact do resell to residents of other states. Such an interpretation, however, not only would fail to accomplish the fundamental purpose of Section 3 (a)(II) to afford exemption only to security distributions which are as a whole essentially local in character, but would

${ }^{47}$ H. R. REP. No. 85, 73rd Cong., Ist Sess. (1933) 7. The Conference Report on the bill as finally recommended by the Conference Committe for passage contains no specific reference to this section or the purposes thereof. H. R. REP. No. 152, 73rd Cong., ist Sess. (1933).

"A further reason for the amendment was undoubtedly to confirm the interpretation previously given to $55(c)$ by the Federal Trade Commission to the effect that securities entitled to exemption on original issuance by reason of that section would retain such exemption in the hands of dealers. See note 22 , supra. 
result in substantial nullification of the registration requirements of the Act. ${ }^{49}$ Accordingly, construing the section in the light of its own evident intent, and of the general purposes of the Act, the Federal Trade Commission adopted the view that, in order that securities may come within the exemption, "it is clearly required that the securities at the time of completion of ultimate distribution shall be found only in the hands of investors resident within the State."50 This view was followed by the Securities and Exchange Commission in the Brooklyn Manhattan Transit Corporation case. ${ }^{51}$ The status of "investor," like that of "underwriter," must presumably be determined by reference to the intention at the time of acquisition. ${ }^{52}$

There can be no doubt that this construction, however clearly dictated by the necessities of the situation, imposes substantial responsibilities upon the issuer of securities who seeks to take advantage of the exemption. Not merely must the issuer ascertain the residence of the immediate purchasers fro: $\mathrm{him}$; he must also satisfy himself either that such purchasers are purchasing for their own investment and without any view to resale, or that such purchasers, if purchasing with a view to further distribution, will themselves confine such distribution to resident investors. If any portion of the issue, however small, is disposed of by way of sale to a nonresident, or to a resident who purchases with a view to distribution and then resells directly or indirectly to a non-resident, the exemption will be lost, not merely for the portion so sold, but for the entire issue. Even a showing of reasonable care in investigation of the residence and intent of the purchasers, whatever its effect as protection against criminal liability for violation of the Act, would seem irrelevant to the question of civil liability under Section I2(I) for the sale of unregistered non-exempt securities.

In this connection again, however, it is necessary to call to mind the primary purpose of Section 3(a) (ii) to exempt local issues which, by reason of the geographical and financial scale upon which they are distributed, are to be regarded as without the proper scope of federal regulation. In cases properly within the scope of the section it will ordinarily be true that the issuer or underwiriter will know, or can readily ascertain, the residence and intent of the purchasers of the issue, and that the distribution of the issue can be effected without any substantial risk of error and consequent liability. Serious risks will ordinarily be encountered only in cases

\$.... Obviously, an act designed to afford regulatory protection for investors in connection with the distribution of new security issues demands that its various component provisions should be construed in harmony with its general purpose. To construe the language of the former Section 5 (c) or of the present Section 3(2)(11) in the way urged by counsel for Brooklyn Manhattan Transit Corporation, so that any issuer might wholly escape from the regulatory provisions of the act by the simple device of making an original sale of a new security issue to one person residing in the same state as the issuer, followed by immediate interstate distribution by that person, would ignore the realities of the mechanics of distributing securities and nullify the expressed purpose of Congress." In the matter of Brooklyn Manhattan Transit Corp., I S. E. C. 147, 161 (1935).

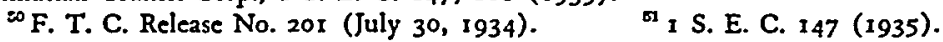

"The term "underwriter" is defined in $\$ 2$ (II) of the Act as including any person who "has purchased from an issuer with a view to, or sells for an issuer in connection with, the distribution of any security." 
of substantial issues the distribution of which is sought to be confined to residents solely for the purpose of avoiding registration under the Securities Act. To the extent that issuers and underwriters seek to bring within the technical requirements of the section issues not genuinely local in character, there may appropriately be imposed upon such issuers and underwriters the fullest responsibility for compliance with such requirements.

In the foregoing discussion, the meaning of the term "issue" has been assumed. This term, however, is not defined in the Securities Act; and although the word is of wide currency in the financial community, its meaning is not sufficiently crystallized in common use to be susceptible of unequivocal definition in vacuo. In fact, the word "issue," used as a noun, may be regarded as a species of financial slang, which in general significance is familiar to everyone, but in precise content must be conceded to take on the color of its surroundings.

Accordingly, in construing the phrase "part of an issue" in Section 3(a)(xI) of the Securities Act, reference must again be made to the broad purpose of that section to afford an exemption for securities distributed in the execution of a plan of financing which as a whole is essentially local in character. Viewed in the light of this purpose, the term "issue," although except in unusual situations doubtless circum. scribed by the concept of "class" (a concept based upon identity of rights) is clearly not coextensive with the latter term. Rather, it may be said that for the purposes of Section 3(a)(II) an "issue" of securities consists of such securities of the same class as are offered for sale, or otherwise disposed of, in the course of a single plan of financing. For many practical purposes, the term "issue" approximates the term "offering."ss

The meaning of the phrase, "part of an issue", becomes important in the case of an issuer who, desiring to raise a certain specific amount of new capital, seeks to dispose of its securities in the first instance through sales exclusively to residents. Finding resident purchasers less abundant than expected, the issuer then proposes to offer the unsold balance to non-residents and, prior to such further offering, undertakes registration, either of the entire amount of securities involved (including those already sold) or merely of the unsold balance. Such an issuer may then be confronted with the fact that even though the entire block of securities involved-the entire "issue"-is registered before sales are made to non-residents, the action of selling any portion of the issue to non-residents even after registration will defeat the exemption which was apparently theretofore available for the portion of the issue sold to residents. Although in such a case a showing of bona fide initial inten-

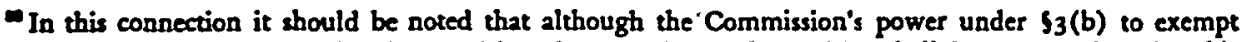
edditional securities is limited by the provision that "no issue of securities shall be exempted under this abbection where the aggregate amount at which such issue is offered to the public exceeds \$roo,000", the Commission's rules adopted in exercise of this power refer repeatedly to the "offering" exempted. See particularly Rule 201, 5(2), and Rule 202, 5(2). However, situations can undoubtedly arise in which a single "issue" is made the subject of several "offerings."
} 
tion to confine the distribution to residents might well support a defense to any criminal proceeding for violation of Section 5 of the Act, it cannot be said with any confidence that a court might not hold in a civil proceeding that subsequent sales to non-residents of a portion of the same class of securities pursuant to the same general financing plan were sufficient to prevent the exemption from attaching to any of the securities sold in the execution of such plan, with the result that a resident purchasing a portion of the issue prior to registration might well be held entitled to prevail in a suit for rescission under Section 12(I) of the Act.

The instance just discussed assumes the unity of plan which is believed to be fundamental to the concept of an "issue" of securities for the purpose of Section 3(a)(II). More difficult questions arise when different blocks of the same security are offered for differing types of consideration, or to clearly distinguishable classes of purchasers. Thus, an issuer desiring to raise $\$ 1,000,000$ in cash by the sale of 10,000 shares of stock may seek to dispose of 5,000 shares to resident members of the public, and 5,000 shares to a non-resident institutional buyer. Similarly, a new corporation formed for the purpose of acquiring and operating a moribund manufacturing plant may propose to issue one-half of its capital stock to non-resident vendors in payment for the properties purchased and the other half to the resident public for the purpose of raising working capital. Even in such cases the sales to residents and those to non-residents, although clearly distinguishable from each other in character and purpose, form interrelated parts of a unitary plan of financing on the part of the issuer, and therefore appear to involve but a single "issue" of securities. On the other hand, if the instance last suggested is varied by an assumption that at the time of the issuance of shares for property it is not within immediate contemplation to offer additional shares to the public for cash, but such an additional offering, necessitated by the supervention of unforeseen business conditions, is stbsequently initiated pursuant to a separate directors' or stockholders' authorization, there would seem little difficulty in regarding the shares comprised within such additional offering as a separate "issue." The question is one of degree, in the determination of which, from an evidentiary point of view, weight may be given to a variety of elements of fact and intention, no catalogue of which can profitably be attempted here. ${ }^{34}$

"Space does not permit an extended discussion of the specialized problem of the application of 53(2)(II) to secondary distributions through underwriters by persons in a control relationship with the issuer. The difficulty of regarding the holdings of a person thus affliated as a separate "issue" for the purposes of $S_{3}(2)(11)$ will, however, be clearly apparent. Such an affiliate, although included within the meaning of the term "issuer" for the limited purpose of defining the term "underwriter," is not an

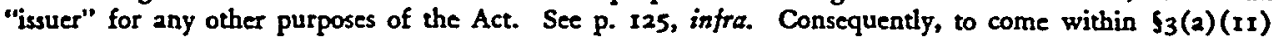
such 2 re-distribution must be made exclusively to residents of the state of incorporation of the actual issuer, rather than to persons residing in the state of residence or incorporation of such affiliate. Furthermore, it seems questionable whether the exemption would be available unless the entire issue of which the redistributed block, upon its original distribution by the actual issuer, formed a part, was upon such original distribution similarly confined to residents of the state of such issuer's incorporation. 
Provisions Exempting Particular Classes of Transactions, Regardless of the Character of the Issuer, the Security, the Issue of Which the Security is a Part, or the Manner in Which the Securuty was Originally Distrubuted

The provisions of Section 3(a)(I), Section 4(I) and Section 4(2) may properly be considered as parts of an integrated whole, specifying the formula to be applied in determining whether a particular transaction is free from the registration and prospectus requirements of the Act, even though the security in question be nonexempt.

These sections evidence two major purposes:

First: To avoid interference with commitments already made, or with offerings in the - process of being made, or about to be made, at the date of passage of the Act.

Second: To avoid fettering with the registration and prospectus requirements of the Act transactions of bona fide investors and the ordinary transactions of security dealers, while at the same time assuring to purchasers of securities the protection afforded by the registration process in those circumstances where such protection is most needed.

Section $3(a)(x)$ exempts "any security which, prior to or within sixty days after the enactment of this title, has been sold or disposed of by the issuer or bona fide offered to the public."ss However, the section contains a proviso to the effect that "this exemption shall not apply to any new offering of any such security by an issuer or underwriter subsequent to such sixty days."

Although this section is in form an exemption of a class of securities, its effect, when considered in the light of the proviso, is that of a transaction exemption.

The aptness of Section 3(a)(I) to accomplish the first major purpose referred to above is obvious, and although the necessity of some provision to accomplish such purpose now seems apparent, there was no comparable provision in the bill originally introduced, except to the extent that such purpose was evidenced by the postponement of the effective date of the Act for ninety days. Important as this provision was in the immunity which it afforded to commitments in effect and to offerings in esse at the effective date of the Act, this aspect of the section is of no great present significance.

The principle adopted in achieving the second major purpose of what have been grouped as the "transaction-exemption" provisions was to differentiate security distribution from security trading. Section 4 , and, to a degree, Section $3(\mathrm{a})(\mathrm{I})$, provide the tools to be used in applying this principle to specific situations. The line of differentiation, like many others in the law, is not a bright one, and the enlightenment of judicial decision will undoubtedly be required to bring clarity into regions where there is no definite demarcation of the two concepts. The line can be best appreciated by considering the effect of the exemptive provisions as applied to the various types of transactions through which an issue of securities may pass. These

\footnotetext{
whe Act was approved by the President on May 27, 1933. The sixty-day period expired on July 26, 1933. Hence, July 27, 1933, is frequently referred to as the "effective date of the Act," although the effectiveness of the Act was postponed only as to the registration and prospectus requirements.
} 
transactions may be classified as follows: (1) transactions by the issuer, (2) transactions by those participating in a distribution of securities, (3) transactions by dealers not participating in any distribution, ${ }^{\mathbf{b} \theta}$ and (4) transactions by others.

(I) Transactions by the issuer. This type of transaction presented to Congress no practical obstacles to the obtaining of adequate data upon which to base registration. It is not surprising, therefore, that the Act, as adopted, required registration in all cases of the offering by an issuer of its own non-exempt securities; except for transactions arising out of certain types of voluntary readjustments or out of bona fide reorganizations subject to court supervision, and except for transactions "not with or through an underwriter and not involving any public offering." 57

The considerations prompting the exemption of transactions of readjustment receive consideration elsewhere in this article. Insofar as new issues were concerned not involving capital readjustments, the House Report suggests that the basis for the limited exemption afforded non-public offerings was that this and the related provisions in Section $4(1)$ broadly drew the line between distribution of securities and trading in securities, "indicating that the act is, in the main, concerned with the problem of distribution as distinguished from trading," and that it therefore "exempts transactions by an issuer unless made by or through an underwriter so as to permit an issuer to make a specific or an isolated sale of its securities to a particular person, but insisting that if a sale of the issuer's securities should be made generally to the public that that transaction shall come within the purview of the act."58 While it may be questioned whether an intent to exclude trading transactions from

${ }^{20}$ In contradistinction to the Securities Exchange Act of 1934, the Securities Act contains no independent definition of the term "broker," but in $\$ 2$ (12) defines the term "dealer" as including any person engaged in the business of dealing or trading in securities, whether "as agent, broker, or principal."

${ }^{\prime \prime}$ Securities Act, $\$ \$ 4(\mathrm{I}), 4(3)$. A transaction exemption was also conferred in effect by the device of excluding from the definition of the term "sale," which includes an "attempt or offer to dispose of" a security for value, any "preliminary negotiations or agreements between an issuer and any underwriter." In addition, early drafts of the Act exempted stock dividends and other security distributions out of earnings or surplus (H. R. 4314, 73rd Cong., Ist Sess. (1933) \$12(d); S. 875, 73rd Cong., Ist Sess. (1933) \$12(d)), offerings of additional stock by a corporation to its own stockholders without the payment of any commissions in connection with the distribution (ibid.), and preorganization subscriptions for stock involving the incurring of no expense and the payment of no commission or remuncration (H. R. $4314,512(\mathrm{~g})$; S. $875, \$ 12(\mathrm{~g})$ ). The exemption for stock dividends and related distributions was eliminated as unnecessary in view of the fact that such distributions, not being made for value, did not involve sales, H. R. (Conf.) ReP. No. 152, 73rd Cong., Ist Sess. (1933) 25, and the exemption for offerings of additional stock to stockholders was omitted as being unwise "unless the stockholders are so small in number that the sale to them does not constitute a public offering" (ibid.) The exemption of preorganization subscriptions was eliminated as unnecessary in view of the provision of $\$ 4(\mathrm{I})$ exempting transactions by any person "other than an issuer, underwriter or dealer" (ibid.) Sed quaere: Section $2(1)$ includes a "preorganization certificate or subscription" within the definition of "security," and the promoter by whom such certificate is issued or to whom such subscription is given would appear to be an issuer the public offering of whose securities would not be exempt.

${ }^{20}$ H. R. REP. No. 85, 73rd Cong., Ist Sess. (1933) 15 to 16 . By virtue of amendment of the Act in 1934, the pertinent clause of $\S_{4}(\mathrm{I})$ was modified by the elimination of the phrase "not with or through an underwriter," the clause as amended providing for the exemption merely of "transactions by an issuer not involving any public offering." This change cannot be regarded as doing more than eliminating a superfluous phrase, on the ground, as stated in the Conference Report on the 1934 amendments, that "there can be no underwriter within the meaning of the act in the absence of a public offer." $H$. R. (Conf.) Rep. No. 1838, 73rd Cong., and Sess. (1934) 41. 
the operation of the registration and prospectus requirements of the Act furnishes a justification for exemption of transactions by an issuer not involving any public offering, it is at least clear that such non-public transactions were not regarded as involving the type of "distribution" with which the Act is primarily concerned. The registration and prospectus requirements relate only to distributions which are public in character.

It is beyond the compass of this article to seek to ascertain the precise limits of the exemption afforded to non-public offerings by an issuer. The "isolated sale" referred to in the House Report, as well as the offering of $\$ 160,000,000$ American Telephone and Telegraph Company debentures through a nation-wide group of underwriters, are easily categoried; but there is a border region of considerable extent where the prudent issuer will register until such time as judicial decision has furnished a rosetta stone of interpretation of the public-offering concept. ${ }^{50}$ The published opinions of the Federal Trade Commission and of counsel to the Securities and Exchange Commission have indicated on the one hand that a non-public offering may be involved even though the issuer's transactions are not limited to an "isolated sale," and on the other hand that an offering, made to a restricted group the membership of which is substantial, may be regarded as public in character even though not open to the world at large. ${ }^{30}$ Although an offering to a rough maximum of twenty-five offerees has been suggested as sufficiently insignificant to fall outside the concept of public offering, ${ }^{61}$ it has been recognized that such a figure does not afford an absolute test and that equal importance may attach to other factors, such as the relationship of the offerees to each other and to the issuer, the number and character of units offered, and the size and manner of the offering. ${ }^{62}$ However, it

\footnotetext{
- The blue-sky laws of a number of states employ the phrase "offered to the public" or its equivalent, but such decisions as have involved an interpretation of the phrase are not particularly illuminating. The test frequently suggested is whether the offer is one which is open to any person who may desire to purchase. See Ex parte Leach, 215 . C2l. 536, 12 P. (2d) 3 (1932); Raynard v. State, 19 Ala. App. 281, 96 So. 723 (1923); People v. Ruthven, 288 N. Y. Supp. 63 I (City Ct. of Rochester, Crim, Branch, 1936). Cf. State v. Whiteaker, 118 Ore. 656, 247 Pac. 1077 (1926), in which the court recognized that an offering somewhat restricted in character might nevertheless be public. The leading English case on the subject is Nash v. Lynde, [1929] A. C. 158, reversing [1928] 2 K. B. 93, where the question was presented as to whether a particular prospectus had been used under such circumstances as to necessitate that it be in the form required by the English Companies Act for a prospectus "issued to the public." Viscount Sumner's opinion includes the following statement: "Anything from two to infinity may serve [as the public]; perhaps even one, if he is intended to be the first of a series of subscribers, but makes further proceedings needless by himself subseribing the whole. The point is that the offer is such as to be open to anyone who brings his money and applies in due form, whether the prospectus was addressed to nim on behalf of the company or not. A private communication is not thus open."

Cf. South of England Natural Gas \& Petroleum Company, Ltd., [1911] I Ch. 573, in which the Court held that there was an offering of shares to the public "none the less because copies were sent only to shareholders in gas companies who were the most likely subscribers."

${ }^{\infty}$ F. T. C. Release No. 97, Dec. 28, I933; Opinion of John J. Burns, General Counsel, Securities and Exchange Comnission, Securities Act Release No. 285, Jan. 24, 1935.

- Letter from Baldwin B. Bane, Chief of Securities Division, Federal Trade Commission, (Prentice. Hazi, Securities Regulation Service, Vol. I, 53817 -B; Commerce Clearing House, Stocks and Bonds LAw Service, Vol. III, par. 2203.03.)

- Securities Act Release No. 285, note 6o, supra.
} 
at least seems clear (I) that, insofar as a numerical test is employed, it is the number of offerees, rather than the number of purchasers, which is material, and (2) that an offering is not rendered non-public merely by restricting it to an issuer's stockholders $^{83}$ or employees. ${ }^{64}$

\section{(2) Transactions by those participating in a distribution of securities.}

(a) Primary distribution-Effectuation of the legislative intent to extend the restrictive features of the Act to all transactions effected in the course of future distributions ${ }^{85}$ required not merely the distinction of such transactions from transactions of a trading nature, but also recognition of two separate classes of persons by whom such transactions might be effected between the point of disposition of the security by the issuer and the point of its absorption by the investing public, namely, (a) those who, by reason of their special relationship to the issuer or their managerial function in the conduct of the distribution, might be regarded as the initiators or promoters of the distribution, and therefore properly subject not only to the registration and prospectus requirements but also to basic responsibility, coextensive with that of the issuer, for the accuracy of the registration statement; (b) those who, having no such special relationship or managerial function, nevertheless serve as the professional conduits through whom the distribution is effected. Broadly speaking, the former are the underwriters, the latter the dealers.

Classification in these respects is effected by Sections 4 (I) and 2(II) of the Act. ${ }^{68}$

* The House (Conference) Report, commenting on the deletion of that provision in the bill as passed by the House which exempted the issuance of additional capital stock of a corporation to its stockholders, states: "Sales of stock to stockholders become subject to the act unless the stockholders are so small in number that the sale to them does not constitute a public offering." H. R. (CoNF.) REP. No. 152, 73rd Cong., Ist Sess. (1933) 25. Furthermore, it would appear that $\$ 4$ (3) of the original Act, exempting the exchange of securities by an issuer with its own security holders, was premised on the assumption that an offering limited to stockholders was not exempt as a non-public offering. See, however, Securities and Exchange Commission v. Federal Compress and Warehouse Company et al., $\mathfrak{i}$. S. D. C., W. D. Tenn., W. Div., order entered Nov, 12, 1936, findings of fact and conclusions of law iled Nov. 14, 1936. At the time of writing, an appeal by the Securities and Exchange Commission irom the order of the District Court is pending before the Circuit Court of Appeals for the Sixth Circuit. See also People v. Ruthven, note 59, supra.

a Among the amendments to the Securities Act proposed at the time of the adoption of the Securities Exchange Act of 1934 was one exempting offerings to an issuer's own employees. The conferees eliminated this amendment on the express ground "that the participants in employees' stock-investment plans may be in as great need of the protection afforded by availability of information concerning the issuer for which they work as are most other members of the public." H. R. (CONF.) REP. No. I838, 73rd Cong., and Sess. (1934) 4I. This expression of intention would appear to be entitled to greater weight than the statement of Senator Fletcher, in debate on the amendments, that he understood that the proposed amendment had been rejected in conference because such an offering would not constitute a public offering. See 78 Cong. Rec. ro490 (June I, I934).

* As has previously been indicated, $\S_{3}(a)(1)$ operated to excmpt transactions by participants in and underwriters of distributions in process at the effective date of the registration requirements of the Act.

"Section 2 ( $\mathrm{I} I$ ) defines the term "underwriter" as follows:

"The term 'underwriter' means any person who has purchased from an issuer with a view to, or sells for an issuer in connection with, the distribution of any security, or participates or has a direct or indirect participation in any such undertaking, or participates or has a participation in the direct or indirect underwriting of any such undertaking; but such term shall not include a person whose interest is limited to 2 commission from an underwriter or dealer not in excess of the usual and customary distributors' or sellers' commission. As used in this paragraph the term 'issuer' shall include, in addition to an issuer, any 
The third clause of the former section, in general terms exempting all transactions by dealers, excepts from such exemption transactions essentially distributive in their nature, and the Act contains no exemption for transactions of such a nature, whether effected by dealers or by underwriters. ${ }^{67}$ Section 2(II), on the other hand, although defining the term "underwriter" generally as including all persons participating in any distribution of securities as well as all persons who undèrwrite or have a "participation" in any such undertaking or underwriting, excepts from the definition those participants whose interest is limited to "a commission from an underwriter or dealer not in excess of the usual and customary distributors' or sellers' commission." Such persons, although having no immunity permitting them to participate in the distribution of unregistered securities or to disregard the prospectus requirements, are relieved of the special responsibility imposed upon underwriters in respect of the contents of the registration statement.

Problems of interpretation arising out of the exception to the definition of the term "underwriter" have been to a considerable extent disposed of by regulations of the Commission adopted under Section I9. Thus, the term "commission" has been interpreted by regulation to include a "spread" received by a distributor or dealer through the purchase of the distributed securities at a price below the offering price. ${ }^{.8}$ Similarly, the phrase "not in excess of the usual and customary distributors" or sellers' commission" has been interpreted as referring to amounts "not in excess of the amount usual and customary in the distribution and sale of issues of similar type and size, and not in excess of the amount allowed to other persons, if any, for comparable service in the distribution of the particular issue" and as excluding amounts paid to a person performing an underwriting or managerial function in the distribution. ${ }^{69}$ A further regulation ${ }^{70}$ of the Commission has answered in the negative the question whether the fact that the underwriter from whom the commission is received may also be an "issuer" by virtue of the last sentence of Section $2(I x)^{71}$ is sufficient to bring within the category of "underwriter" the dealer receiving such commission.

(b) Secondary distribution-The foregoing discussion has proceeded in a free use of the term "distribution," without express consideration of the meaning of that term. "Distribution," although a cornerstone of the Act, is not defined in the Act, and the concept seems to have received even less attention from the courts than its correlative, "public offering." Viewed in relation to the purposes of the Securities

person directly or indirectly controlling or controlled by the issuer, or any person under direct or indirect common control with the issuer."

"Even preliminary negotiations between underwriters were granted no privileged status. In commenting upon the exception in the definition of the term "sale" for prelimi zary negotiations between issuers and underwriters, the House Committee stated that: "The exception, however, extends no further than the agreement between issuer and underwriters, so as to delay the actual organization of the selling group and the disposition of the security to the dealers until the registration statement shall have become effective." H. R. REP. No. 85, 73rd Cong., Ist Sess. (1933) 12.

* Rule I4I (a).

Dule 14 I (c).

${ }^{70}$ Rule I 4 I (b).

${ }^{7}$ See note 66, supra. 
Act, however, it would seem that the best approach is to regard the term "distribution" as embracing the several steps involved in the process whereby, in the course of a public offering, a single block of securities is dispersed and comes to rest in the hands of members of the public who purchase for investment. ${ }^{72}$ From this standpoint, it is clear that "distribution" may be effected not merely of a block of securities which are the subject of present issuance, but also of any block of outstanding securities. To the small investor, it is relatively immaterial whether his securities derive from the issuer directly or from some large holder who has undertaken a liquidation of his holdings. The need for basic information as to the factual background of the security may be as great in the one case as the other.

The various methods by which, in the course of consideration of the Act, it was proposed to deal with this problem of "secondary distribution," both as to securities outstanding at the effective date of the Act, and as to securities subsequently issued, indicate its intrinsic difficulty. The Act, in the form in which it was originally introduced, although apparently intended by its framers not to apply to securities at the time outstanding, clearly brought within its provisions all outstanding securities, other than securities of specified classes of issuers, certain real estate mortgage bonds of limited amount, and seasoned securities of small issuers having a fixed return and not being in default. ${ }^{73}$ Such exemption as was afforded to transactions in nonexempt securities was limited to transactions by fiduciaries, ${ }^{74}$ transactions by bona fide pledgees or mortgagees, ${ }^{7 \sigma}$ transactions involving the distribution, sale or readjustment of securities within the corporate family, ${ }^{76}$ transactions involving the sale of certain secured obligations to a limited number of persons, ${ }^{77}$ transactions involving the sale of preorganization subscriptions ${ }^{78}$ and "isolated transactions in which any security is sold, offered for sale, subscription, or delivery by the owner thereof, or by his representative solely for the owner's account, such sale or offer for sale, subscription, or delivery not being made in the course of repeated and successive transactions of a like character by such owner for the purpose of engaging in the purchase

7 As illustrative of this approach, note the following comment from H. R. REP. No. 85, 73rd Cong., Ist Sess. (1933), 16, upon the proposed limitation excluding from the exemption proposed for transactions by dealers transactions occurring during the year following public offering: "The period of a year is arbitrarily taken because, generally speaking, the average public offering has been distributed within a year." Of similar import is the comment in H. R. (CoNf.) Rep. No. 1838, 73rd Cong., 2nd Sess. (1934) 4I: "The Commission has recognized by its interpretations that a public offering is necessary for distribution. Therefore there can be no underwriter within the meaning' of the Act in the $2 b s e n c e$ of 2 public offer. ...."

The terms "investment" and "investor" are also not susceptible of ready definiticn, in view of the manifold combinations of motives which may impel the purchase of a security. As used in this article, however, the term "investor" refers to the person who, though he may not be unwilling to take advantage of a rapid appreciation in market value, is primarily interested in the "long pull," as distinguished from a quick turn-over profit. In this sense even a security of obviously speculative merits may be made the subject of "investment."

${ }^{7}$ H. R. 43I4, 73rd Cong., Ist Sess. (r933) Srr; S. 875, 73rd Cong., Ist Sess. (1933) 511.

"H. R. 4314, S12(a); S. 875, \$12(a).

TH. R. $4314,5 \$ 12(d), 12(f) ;$ S. $875,5512(d), 12(f)$.

$\pi$ H. R. 4314, S12(c); S. 875, $512(\mathrm{c})$. *H. R. 4314, $512(\mathrm{~g}) ; \mathrm{S} .875,512(\mathrm{~g})$. 
and sale of securities as a business, and such owner or representative not being the underwriter of such security." 79

The defects inherent in the proposed bill, as applied both to transactions in securities outstanding at the effective date of the Act and to non-distributive transactions in securities subsequently issued, were promptly recognized by its critics. Unless issuers in their discretion had seen fit to register, the great bulk of securities outstanding in the hands of dealers for their own account would have been frozen, ${ }^{80}$ with drastic consequences to existing values in the security markets. Furthermore, as to all non-exempt securities, whether outstanding or subsequently issued, any dealer, regardless of the remoteness of the particular transaction from the distribution process, would have been under a duty to furnish a prospectus meeting the requirements of Section 8.

In the Senate it was sought to cure these defects by exempting any securities sold and delivered prior to the date of approval of the Act to purchasers other than underwriters, selling agents, assigns or representatives of the issuer, with a proviso that the exemption should not be applicable in the case of a sale, whether in one or a series of transactions, of securities sold having an aggregate par or stated value of more than \$roo,000. In cases in which, by reason of such proviso, the exemption was not available, the registration statement was to consist of a statement signed by the owner (or owner and dealer, if sales were effected through a dealer), containing a copy of the selling literature, together with such other information as the Federal Trade Commission might require.81 The problem of transactions in securities issued subsequent to the date of approval of the Act was dealt with by a provision exempting "isolated transactions," similar to that contained in the original bill.

An entirely different approach in dealing with the problem of outstanding securities was adopted by the revised House bill, as introduced on May $3,1933,{ }^{82}$ and was carried into the Act as adopted. The revised bill recognized that registration, to be of significance, must be effected by the issuer, and that therefore the registration requirements of the Act, so far as outstanding securities were concerned, should be imposed only in the event of a redistribution of such securities by the issuer itself or by a person having such relationship, direct or indirect, to the issuer as to be in a position to obtain registration by the issuer. This was accomplished, as has been elsewhere indicated in this article, by exempting both outstanding securities and securities in the process of being offered but providing for the termination of such exemption upon a re-offering of such securities by an issuer or underwriter, ${ }^{83}$ and by

H. R. 4314, $512(c)$; S. 875, 512(c).

- See amendment proposed by Mr. Huston Thompson, Hearing before the Committee on Interstate and Foreign Commerce on H. R. 4314, 73rd Cong., Ist Sess. (1933), at 222.

${ }^{n}$ H. R. 5480, 73rd Cong., Ist Sess. (1933), as printed with the amendment of the Senate, May 10, 1933, $\$ 12(f)$. The extent to which the liability provisions of the bill would have been applicable to this "owner-dealer" type of registration statement is not clear.

$\because$ H. R. 5480, 73rd Cong., ist Sess. (1933).

- Section $3(2)(1)$ of H. R. 5480, supra note 82, provided for termination of the exemption only upon re-offering "by or through an underwriter." In the Act as adopted the exception was broadened to include re-offering "by $2 n$ issuer or underwriter." 
broadening the definition of "underwriter" beyond that contained in the original bill, so as to comprehend within its terms a person sponsoring the distribution of securities owned by a person controlling, controlled by, or under common control with, the issuer of such securities. ${ }^{84}$

As to non-exempt securities issued after the passage of the Act, the exclusion from Section 4 of any exemption for transactions by underwriters, coupled with the comprehensive effect of the definition of "underwriter," of course operated to bring within the purview of the registration and prospectus requirements transactions of secondary distribution on behalf of an affiliated person, regardless of whether the securities involved in such transactions had been originally issued in the course of a public or a private offering. ${ }^{85}$ Furthermore, even though it may be doubtful whether re-registration of securities originally offered publicly and registered is required by the Act upon redistribution by the issuer or secondary distribution by an affiliated person, it seems clear that even in such cases the distributor is under a duty to deliver a prospectus, and is charged with the responsibility of an underwriter for the contents of a registration statement. Such a distributor may for practical reasons find it advisable to cause the issuer to effect amendment of the original statement.

It follows from the foregoing that, under the Act as adopted, a distribution of a substantial block of securities owned by a person not affiliated with the issuer may be made without registration, assuming, of course, that such distribution is not effected by or for the issuer. Although in many such cases the registration process would undoubtedly afford definite benefits to the purchaser, the limiting of the requirement of registration to those cases of secondary distribution in which registration by the issuer may be compelled is completely justified upon consideration of the practical difficulties inherent in the effecting of registration by a non-affiliated person, the probable inadequacy of any registration thus effected, and the public interest in not hampering the free interchange of outstanding securities in honest transactions.

84 This result was achieved by the last sentence of $\$ 2(\mathrm{II})$ of H. R. 5480 , supra note 81 , which was carried over without change into the Act as adopted. See note 66, supra.

The purpose of the framers of H. R. 5480 in this respect is clearly indicated by the following comment on this sentence contained in the report of the Committee on Interstate and Foreign Commerce, reporting out H. R. 5480 to the House:

". . . Its second function is to bring within the provisions of the bill redistribution whether of outstanding issues or issues sold subsequently to the enactment of the bill. All the outstanding stock of a particular corporation may be owned by one individual or a select group of individuals. At some future date they may wish to dispose of their holdings and to make an offer of this stock to the public. Such a public offering may possess all the dangers attendant upon 2 new offering of securities. Wherever such a redistribution reaches significant proportions, the distributor would be in the position of controlling the issuer and thus able to furnish the information demanded by the bill. This being so, the distributor is treated as equivalent to the original issuer and, if he seeks to dispose of the issue through a public offering, he becomes subject to the act. The concept of control herein involved is not a narrow one, depending upon a mathematical formula of 51 percent of voting power, but is broadly defined to permit the provisions of the act to become effective wherever the fact of control actually exists." H. R. REP. No. 85, 73rd Cong., xst Sess. (1933) 13-14.

Sales by an affiliated person not through an intermediary may, however, be exempt. See pp. 125-127, infra. Transactions of redistribution by the issuer are of course non-exempt by virtue of the last clause of $\varsigma_{3}(\mathrm{a})(\mathrm{I})$. 
(3) Transactions by dealers not participating in any distribution.

(a) Transactions by dealers for their own account-In the foregoing discussion reference has been made to the burdens which the Act in its original form would have imposed upon dealers, both in respect of their transactions in securities outstanding at the time of passage of the Act and in respect of their transactions in securities subsequently issued. The approach finally adopted in the Act was to exempt from the registration and prospectus requirements (I) all dealers' transactions in securities outstanding or in process of being offered at the effective date of the $\mathrm{Act}^{86}$ and (2) all dealers' transactions of a trading, as distinguished from a distributive, nature in securities subsequently offered.

Exemption of transactions of the first category was achieved with relatively little difficulty by the provisions of Section $3(a)(x)$. As regards transactions of the second category, however, the problem was presented of providing a workable distinction between transactions which are distributive in character and those which are not. Any statutory test based upon the intrinsic nature of each particular transaction would necessarily be both ambiguous in its application and subject to easy evasion. Accordingly, recognizing that both compliance with, and enforcement of, the provisions of the Act would be advanced by a test which made up in certainty what it lost in abstract accuracy, Congress adopted the principle of subjecting to the registration and prospectus requirements all transactions by dealers occurring within one year after the first public offering. ${ }^{87}$ As pointed out by the House Committee on Interstate and Foreign Commerce: "The period of a year is arbitrarily taken because, Fnerally speaking, the average public offering has been distributed within a year, and the imposition of requirements upon the dealer so far as that year is concerned is thot burdensome."88 In aid of the test thus adopted, appropriate provision was made to toll the one-year period for any time during which a stop-order was in effett, and to exclude from exemption transactions, even after the expiration of the one-year period, in securities in fact constituting part of an unsold allotment acquired by the dealer as a participant in the distribution by an issuer or underwriter. On the other hand, it was provided that the exemption for transactions more than one year after the public offering should extend even to transactions by dealers who had acted

" Such was the effect of $\$_{3}(a)(x)$.

"Section $4(\mathrm{x})$ provides in part that $\$ 5$ shall not apply to "transactions by a dealer (including an underwriter no longer acting as an underwriter in respect of the security involved in such transaction), except transactions within one year after the first date upon which the security was bona fide offered to the public by the issuer or by or through an underwriter (excluding in the computation of such year any time during which 2 stop order issued under section 8 is in effect as to the security), and except transactions as to securities constituting the whole or a part of an unsold allotment to or subscription by such dealer as a participant in the distribution of such securities by the issuer or by or through an underwriter." In the Act as originally adopted in 1933, it was provided that the one-year period should be calculated from the last, rather than the first, date of public offering. This was recognized by Congreas in r934 25 an error and the word "first" was substituted for "last." See H. R. (CoNF.) Rep. No. 1838, 73rd Cong., 2nd Sess. (1934) 4x.

-H. R. REP. No 85, 73rd Cong., Ist Sess. (1933) 16. 
as underwriters in the distribution of the security in question, provided such dealers were no longer acting as participants in such distribution.

It is to be noted that the one-year period during which the dealer's transactions are non-exempt is predicated upon a public offering by an issuer or underwriter, and that it is the first date of such offering which starts the running of the period. The following results are therefore implicit in the provisions of Section 3(a)(x) and Section $4(\mathrm{I})$, as they relate to transactions in outstanding securities by dealers not acting as participants in the distribution:

First: As to securities sold or disposed of by the issuer, or made the subject of public offering before July 27, 1933:89 Dealers' transactions are exempt, regardless of any new public offering of such securities by the issuer or an underwriter.

Second: As to securities privately offered, but not sold or disposed of, before July 27 , 1933: Dealers' transactions are exempt until there is a public offering of such securities by the issuer or an underwriter, whereupon such transactions become non-exempt until one year after the first date of such public offering.

Third: As to securities first publicly offered on or after July 27, 1933: Dealers' transactions are non-exempt until one year after the first date of such public offering, and are thereafter exempt. 90

Fourth: As to securities offered privately on or after July 27, 1933, and not previously the subject of public offering: Dealers' transactions are exempt until there is a public offering of such securities by the issuer or an underwriter, whereupon such transactions become non-exempt until one year after the first date of such public offering.

The consideration of dealers' transactions has thus far assumed that the public offering, the making of which necessitates registration, is of an entire class of securities, or that, if it is of an additional issue of a class a portion of which is already outstanding, the securities composing such additional issue may be so earmarked as to enable dealers in future transactions to determine whether the securities dealt in form a part of an exempt or a non-exempt issue. Such earmarking would noc seem impracticable, even though it might result in a slight price differential in future trading in securities the holders of which would have identical contractual rights. ${ }^{\text {.1 }}$ It is not uncommon to identify by distinguishing letters or dates successive issues of bonds issued under the same indenture or of preferred stock having similar priorities, and, although such series may have slight differences in their interest or dividend rates or in other respects, the existence of such differences is not essential.

Whatever may be the theoretical possibilities of the earmarking of issues, it is a practice which issuers have in fact not followed. The result is that where an offering

- See note 55, supre.

* Although the question is not entirely free from doubt, it would seem that the exemption once acquired would continue even though the same securities were made the subject of a secondary distribution through an underwriter for 2 person in control of the issuer. This conclusion is consistent with the language of $54(x)$, and is necessary to relieve the dealer from the burden of tracing the history of securities dealt in to ascertain whether they come from a block accumulated in the hands of a controlling person. The same conclusion would seem to follow in the case of securities reacquired and reoffered by the issuer.

"The purchaser of the "registered" security would, of course, have the benefit of the additional rights afforded by the Securities Act. 
is made of an additional block of a class of stock already outstanding and subject to active trading, particularly on a securities exchange, time and the transfer agent quickly erase any ready identification of the shares of the new issue which might initially be possible by reference to certificate numbers. ${ }^{92}$ As a practical matter, therefore, the dealer in a security of a class some portion of which has first been publicly offered by the issuer or an underwriter within a year utilizes the mails or interstate commerce at his peril in connection with the offering or delivery of such security unless he furnishes a prospectus meeting the requirements of the Act at the time required by the Act. ${ }^{93}$ Insofar as transactions on registered national securities exchanges are concerned, a practical solution of the problem has been afforded by the adoption by the Commission of a rule providing for the furnishing to the exchange of an adequate supply of prospectuses which are kept available to the public by the exchange. ${ }^{94}$ It should be carefully noted that this rule is inapplicable to transactions otherwise than on an exchange, even though the security in question is registered under the Securities Exchange Act.

(b) Transactions by dealers for account of others-Although the Securities Exchange Act of 1934 undertook to classify as "brokers" or "dealers" persons engaging in the securities business, ${ }^{95}$ no such segregation was made in the Securities Act, which defines a dealer to include "any person who engages either for all or part of his time, directly or indirectly, as agent, broker, or principal, in the business of offering, buying, selling, or otherwise dealing or trading in securities issued by another person." scope of exempted transactions all 'brokers' transactions, executed upon customers' orders on any exchange or in the open or counter market, but not the solicitation of such orders." ${ }^{27}$ It is to be noticed that although the running of the period during which dealers' transactions generally are non-exempt is tolled by the entry and continuance in effect of a stop-order, there is no such limitation on the applicability

an Such erasure results not so much from the transfer of a specified number of registered shares from one person to another, as from the breaking up of round lots into odd lots and the subsequent assenibly of round lots, and from the operations of the stock clearing corporation or other exchange agency performing similar functions.

If the dealer fails to deliver a prospectus, he takes the risk that the purchaser may at some future date trace the purchased shares to their origin and show them to be shares which were the subject of the public offering. In such a case $\$ 12(1)$ would afford the purchaser a right to rescind his purchase or recover damages from the dealer.

Wule 153 .

${ }^{\infty}$ Section $3(2)(4)$ of the Securities Exchange Act.of 1934 provides: "The term 'broker' means any person engaged in the business of effecting transactions in securities for the accuunt of others, but does not include a bank." Section $3(2)$ (5) provides: "The term 'dealer' means any person engaged in the business of buying and selling securities for his own account, through a broker or otherwise, but does not include a bank, or any person insofar as he buys or sells securities for his own account, either individually or in some fiduciary capacity, but not as a part of a regular business."

Securities Act, \$2(12).

"It need hardly be pointed out that although by reason of the provisions of the Securities Exchange Act of 19342 security may not be dealt in on a national securities exchange unless it is registered under that Act or exempted from registration, such registration or exemption is immaterial insofar as the requirements of the Securities Act are concerned. In this article there is no attempt to discuss the provisions or application of the Securities Exchange Act. 
on the exemption for "brokers' transactions." The result, as was pointed out by the House Committee, was not merely to permit individuals to dispose of their securities through normal channels without restriction, but also to make possible an open market for securities, despite the entry of a stop-order. "Purchasers, provided they are not dealers, may thus in the event that a stop order has been entered, cut their losses immediately, if there are losses, by disposing of the securities. On the other hand, the entry of a stop order prevents any further distribution of the security." ${ }^{88}$

In view of the fact that, under accepted methods of trading in vogue at the time of passage of the Act, the same house was commonly engaged in security transactions both for its own account and for the account of others, there can be no doubt but that the exemption provided by Section 4(2) was intended by Congress to cover only transactions actually executed in a brokerage capacity, and that no exemption for transactions by a dealer can be predicated upon the mere fact that the business of the particular dealer consists in some part of business as a broker.

The exemption, it will be noted, is qualified by the phrase "but not the solicitation of such orders." Upon the strict langtage of the proviso, it is at least arguable that in cases where customers' orders are solicited, only the solicitation itself is nonexempt, the transaction of purchase or sale effected upon the order retaining its exemption in spite of the solicitation. This construction is not meaningless if it is recalled that the terms "offer to sell" and "offer for sale" are defined in Section 2(3) of the Act as including any "solicitation of an offer to buy"; in view of this language the solicitation of a buying order by a buying broker from his customer would of itself, if effected through use of the mails or interstate commerce, constitute a transaction prima facie falling within the prohibitions of Section 5. The Commission, however, has taken the view that the occurrence of any solicitation is effective to defeat the exemption not only for the act of solicitation but also for the transistion effected pursuant to the order solicited. This result is held to follow even though the solicitation is effected without any use of the mails or interstate commerce.99

The position has also been taken that the exemption, if available, extends only to the broker's end of the transaction, and that therefore an issuer or underwriter selling through a broker who had not solicited the selling order would be subject to Section 5 , even though the broker himself were subject to no such restrictions. ${ }^{100}$

\section{(4) Transactions by others.}

The first clause of Section 4(I) of the Act exempts from the registration and prospectus requirements "transactions by any person other than an issuer, underwriter or dealer." As indicated in the House Report, this exemption further exempli-

${ }^{\infty}$ H. R. Rep. No. 85, 73rd Cong., Ist Sess. (1933) i6.

- In the Matter of Brooklyn Manhattan Transit Corp., I S. E. C. 147, 171-172 (1935); Securities Exchange Act Release No. 260 (June 6, 1935).

${ }^{100}$ F. T. C. Release No. 131 (March 13, 1934). 
fies the concern of the Act "with the problem of distribution as distinguished from trading." 101

In general, this clause presents no difficulties. The few problems of interpretation which do arise spring from the meaning of the term "underwriter" as applied to various situations. ${ }^{102}$

A holder of stock may be one of a hundred thousand holders to whom are offered rights to subscribe to additional stock of the same issuer. He exercises his rights with a view to the resale of the stock thus acquired. Is he an underwriter? Undoubtedly not, even though he has acquired from the issuer otherwise than for investment. On the other hand, if a dominant stockholder were to cause a general offer of securities of the dominated issuer to be made to himself and a few scattered stockholders, with a view to distribution of the stock to be acquired by him, such stockholder might properly be held by a court to have no benefit of the exemptive provision in question. Between these two extremes may lie an infinite variety of cases in which determination of the status of the purchaser as an underwriter may require a full knowledge and a realistic consideration of all the circumstances surrounding the purchase and resale.

Similar questions may arise as to the propriety of predicating the status of underwriter upon activities which as a legal matter may amount to selling "for" the issuer of the securities sold. For example, the $\mathrm{X}$ Bank accepts as security for a substantial loan to Corporation $\mathrm{Y}$ bonds issued by Corporation $\mathrm{Z}$, controlled by $\mathrm{Y}$. The loan, it is assumed, is made in good faith, with no purpose of effecting any distribution of the pledged bonds. The note or instrument of pledge contains a provision empowering $\mathrm{X}$, in the event of default on the loan, to sell the pledged bonds privately or publicly for account of $\mathrm{Y}$, applying the proceeds toward the payment of the loan and returning to $Y$ any sums remaining after the payment of the expenses of sale. $A$ default occurring, $X$ desires to sell the bonds, and enters into negotiations with $B$, an investment banking house, for the sale of the bonds to it, B proposing to organize a group of dealers to act as a selling group in the disposition of the bonds. Despite the default, $\mathrm{X}$ is not in control of $\mathrm{Y}$ and cannot compel registration of the bonds by $Z$. May Z, by its refusal to register, prevent disposition of the bonds by $\mathrm{X}$ except in a non-public offering? Although the definition of the term "underwriter," if torn from its context, is admittedly broad enough to include the pledgee who, although not in a position to compel registration, finds it necessary in the collection of his debt to utilize the usual channels of distribution, consideration of the definition from a functional point of view would without doubt lead a court to conclude that a bona fide pledgee in such a situation is not to be regarded as an underwriter. ${ }^{108}$

${ }^{200}$ H. R. REP. No. 85, 73rd Cong., Ist Sess. (1933) 15.

20 For definition of the term "underwriter," see note 66, supra.

200 The Act, as proposed to Congress and as originally passed by the Senate, expressly exempted sales "by or for the account of a pledge holder or mortgagee selling or offering for sale or delivery in the ordinary course of business and not for the purpose of avoiding the provisions of this Act, to liquidate a bona fide debt, a security pledged in good faith as collateral for such debr." H. R. 4314, 73rd Cong., 
Another question of considerable importance may arise under this clause in the case of a sale of securities by a person controlling, controlled by, or under common control with the issuer of such securities. As has already been indicated, ${ }^{104}$ the term "underwriter" is so defined as to include a person participating in a distribution by a person in such a control relationship with the issuer; the device used to this end is to provide that the term "issuer," as used in Section 2(II), shall include any person in such a control relationship with the actual issuer. As evidenced by the definition of the term "issuer" for the general purposes of the Act, ${ }^{108}$ however, as well as by the context of certain other sections of the Act in which the term "issuer" appears, ${ }^{108}$ the affiliated stockholder cannot be regarded as an issuer for any purpose save the limited one of determining the status, as an underwriter, of a person selling for or purchasing from him. For the purpose of exemption under Section 4(I), it is clear that an affiliated stockholder is a person "other than an issuer." Accordingly, securities owned by an affiliated stockholder, whether outstanding at the effective date of the Act or subsequently issued, may be publicly offered by such stockholder without compliance with the registration and prospectus requirements of the Act, so long as no intermediary falling within the definition of the term "underwriter" is involved in the offering. ${ }^{107}$

Ist Sess., (1933) \$12(b); S. 875, 73rd Cong., Ist Sess. (1933) \$12(b). On first impression, it might appear that the elimination of this section in the Act as passed is indicative of a legislative intent to require registration in the situation suggested. On the other hand, the $A c t$, as originally introduced, contained no concept of "underwriter" comparable to that subsequently adopted by the House and retained in the Act in its final form; and the exemption which the original bill afforded to isolated transactions by non-dealers (H. R. 4314, $\$ 12$ (c); S. 875, $\$ 12$ (c); (see Pp. II7-11 8 supra) would in many instances not have extended to transactions of liquidation by a pledgee. Furthermore, the Conference Report (H. R. (Conf.) Rep. No. 152, 73rd Cong., Ist Sess. (1933)) makes no mention of the omission of the section in question, or of the omission of a closely related provision in the original bill exempting sales by fiduciaries and receivers and trustees in insolvency or bankruptcy, despite the fact that the Report diseusses in some detail the respects in which the bill as agreed upon by the conferees departs in substance both from the bill as originally passed by the House and from the Senate amendment of that bill (which included both of the exemptive provisions just referred to). The silence of the Conference Report is indicative of the fact that the exemptive provisions of the bill as reported out of the conference rendered unnecessary the retention of the earlicr specific exemption of pledgees' and fiduciaries' transactions. .

It may be urged that the pledgee could insist upon registration by the issuer at the time of making of the loan. But this is equally true of the non-controlling "private" offeree who purchases for investment. If the latter's purchase is bona fide, he is free to resell at some later date without registration, even though he utilizes the normal channels of security distribution. A fortiori, the bona fide pledgee who distributes only because forced to do so by the default of the issuer or its affiliate should not be prevented from doing so by reason of the unwillingness of the issuer or, its affliate to effect registration.

${ }^{200}$ See pp. $118-119$, supra. $\quad{ }^{100} \$ 2(4)$.

${ }^{200}$ E.g., $\$ 3(a)(9) ; \$ 3(a)(11) ; \$ 6(a) ; \$ 11$, particularly when read in conjunction with $\$ 15$; Sched. A; Sched. B.

${ }^{107}$ Of course, this result would not follow if the affliated stockholder had purchased the stock in question, with a view to its distribution, from the actual issuer or some other affiliated stockholder, in which event the affiliated stockholder who sells would himself be an underwriter. It may also be supposed that the courts would not hesitate to apply recognized principles of corporate law if the facts were such as to warrant a disregard of the corporate entity, in which event there would be involved in substance an offering by the actual issuer. Furthermore, the courts would undoubtedly pierce any form of device utilized for the obvious purpose of avoiding the restrictions imposed upon a public offering by the issuer, as for example, where an affiliated stockholder sold shares owned by him, without the use of an intermediary, 
It is believed that this differentiation between transactions of resale effected directly by a controlling stockholder to persons purchasing for investment and those effected through the interposition of an intermediary rests upon sound grounds. In narrowing the scope of transactions as to which registration would have been required under the bill as originally proposed, Congress appropriately recognized that registration, to be significant, must be effected by the actual issuer, and that the requirement of registration was therefore perforce limited to those transactions as to which there was or had been some means of compelling such action by the issuer. However, it did not necessarily follow that registration should be required in all such cases. Even though the expense of registration may be met by the controlling stockholder, who may also indemnify the issuer and its officers and directors against liability, a fair consideration of the interests of the affiliated stockholder, as an investor, warrants relieving him of this expense and liability in those cases where the need of affording to the public the protection afforded by registration may fairly be regarded as limited. In solving this problem, Congress might have called for registration in any case of public offering by the affiliated stockholder, or in any case where the aggregate offering price was in excess of a stated minimum. Instead of adopting either course, Congress apparently felt that the proper test to be applied was whether the disposition made by the controlling stockholder was of such a character as to be likely to involve the use of the machinery of public distribution, and that there was little likelihood of such use unless the affliated stockholder were to utilize the services of an intermediary.

In this connection, the question immediately occurs whether the fact that an affiliated stockholder disposes of certain of his holdings by means of brokerage transactions effected on a securities exchange or in the open or counter market subjects such transactions to the registration and prospectus requirements of the Act. Is the broker an "underwriter," as that term is defined in the Act, and, if so, is the transaction a non-exempt transaction? The broker is obviously "selling for" the affliated stockholder, who, for the purpose of determining the status of the broker, is, under Section 2(II), to be regarded as the "issuer." However, Section 2(II) requires more than this single factor. If the intermediary is to be an underwriter, the sale effected for the affiliated stockholder must be "in connection with the distribution of" the security. It is possible that the offering by the affiliated stockholder, in a reasonably active market, of a small portion of his holdings, without resort to any selling efforts other than the mere placing of orders with the affiliated stockholder's own broker and the execution by the latter of such orders in the normal course of business, and without any effort on the part of the stockholder, his broker, or others acting in conjunction with him, to support, stabilize, or otherwise influence the market for the security in question, would be held to involve no "distribution"

pursuant to an understanding that the proceeds of the salc would be turned over to the actual issuer against the issuance by it to the affiliated stockholiter of shares to replace those sold by him. 
of such security, as that term is used in Section 2(II), with the result that the broker would not occupy the status of underwriter. However, apart from this consideration, it would appear that even though a transaction is not exempt under Section $4(x)$, it may nevertheless be exempt under Section 4(2). It follows that, even though the broker acting for the affiliated stockholder were to be held an underwriter, it would still be possible for his transactions to be entitled to the exemption afforded by Section 4(2) for unsolicited "brokers' transactions." 108 Implicit in this term would appear to be the requirement that the purported broker receive only his usual and customary commission in connection with such sales and that he effect such sales only by means and methods customarily employed by a broker in the usual and regular execution of customers' orders. It would seem inevitable, as a practical matter, that where an affiliated stockholder is endeavoring to effect a disposition of all or a substantial part of his holdings, a broker or brokers executing transactions on his behalf would go beyond the functions properly exercised in transactions within Section 4(2), and would therefore not be entitled to exemption under that section.

I00 See pp. 122-1 23, supra. 